\title{
Propozycja podstawy programowej do języka polskiego
}

\author{
|Krzysztof Biedrzycki \\ Uniwersytet Jagielloński, Kraków \\ IORCID: 0000-0002-5110-6986
}

Przedstawiam do dyskusji autorski projekt podstawy programowej do języka polskiego. Dlaczego? Przecież zmiany programowe zostały wprowadzone niedawno i byłoby ryzykowne dopominanie się o kolejne reformy. Zresztą, ponieważ jakiekolwiek decyzje w tej materii mają charakter polityczny, w bliskiej perspektywie raczej nie należy się spodziewać ruchów w tym kierunku. Dyskusja powinna się jednak toczyć niezależnie od jej wyniku.

Obowiązująca od 2017 roku podstawa programowa spotkała się z surową krytyką, wielu nauczycieli podkreśla, że jest ona trudna w realizacji. $\mathrm{Na}$ realną ocenę jej skutków jest jednak za wcześnie. Co prawda dwie edycje egzaminu ósmoklasisty (2019 i 2020) pokazały, że wyniki były mniej więcej porównywalne z wynikami egzaminu gimnazjalisty z poprzednich lat, ale tak naprawdę nie da się ich porównywać, tak jak nieporównywalne są wyniki egzaminu tego samego rodzaju w kolejnych latach. Nie wiemy więc, $\mathrm{w}$ jakich obszarach dzieci sobie radzą dobrze, w jakich gorzej. A zwłaszcza - w jakim stopniu wpłynęła na to podstawa programowa. Na naukową ocenę jej rezultatów dopiero przyjdzie czas. Poniższa propozycja nie tyle więc pozostaje $\mathrm{w}$ opozycji do obecnej podstawy programowej, ile stanowi jej alternatywę.

Do pogłębionej refleksji nad tym, czego i jak należy uczyć, skłania nas obecnie szczególna sytuacja, gdy wskutek pandemii covid-19 cała edukacja została postawiona w stan krytycznego przewartościowania. Zamknięcie szkól, przeniesienie nauczania do sieci, konieczność odniesienia się do zupełnie nowej aury emocjonalnej i poznawczej uczniów spowodowały, że dotychczasowe treści i metody nauczania zostały poddane podważeniu. Trzeba uczyć i uczyć się inaczej, nawet po powrocie do sali lekcyjnych. 
O założeniach, jakie mi przyświecały podczas opracowywania projektu podstawy programowej, napisałem szczegółowo w artykule-manifeście Podstawa programowa do języka polskiego. Jaka może być? Jaka powinna być? Propozycja refleksji opublikowanym w tomie Polonistyka i świat wartości. Edukacja polonistyczna jako wartość ${ }^{1}$. Tutaj przedstawię tylko najważniejsze punkty, w których uzasadnię założenia i konstrukcję tekstu.

1. Podmiotem i adresatem dokumentu jest uczeń. Czyli młody człowiek, przed którym całe dorosłe życie. Jego osobowość, integralny rozwój, dobrostan. Przedmiot język polski odgrywa tu szczególną rolę, gdyż mocno oddziałuje (powinien oddziaływać) na jego emocje, postrzeganie innych ludzi, porozumiewanie z nimi. Celem jest wykształcenie i formowanie człowieka samodzielnie myślącego, o szerokich horyzontach, posiadającego przynajmniej podstawową ogładę humanistyczną, otwartego na literaturę, sztukę, refleksję. Człowieka skutecznie i z zachowaniem zasad etycznych komunikującego się z innymi. A zatem - dobrze funkcjonującego w społeczeństwie. Przedmiot nazywa się „język polski”, gdyż obejmuje komunikację w języku i w obrębie kultury polskiej, która łączy obywateli naszego państwa, kultury narodowej, ale równocześnie otwartej na innych. Ważne jest kształcenie świadomej tożsamości narodowej i jednostkowej. Założenie aksjologiczne jest istotne, gdyż od niego zależy rozłożenie akcentów i wyznaczenie hierarchii celów kształcenia.

2. W poniższej propozycji edukacja polonistyczna ma wyznaczone dwa obszary kompetencji, ściśle z sobą powiązane: kompetencje językowo-komunikacyjne oraz kompetencje literackie i kulturowe. Pokrywają się one $\mathrm{z}$ dwiema kompetencjami kluczowymi opisanymi w Zaleceniu Rady Unii Europejskiej z 22 maja 2018 roku$^{2}$ : kompetencji porozumiewania się w języku ojczystym (kompetencje w zakresie rozumienia i tworzenia informacji) oraz kompetencji w zakresie świadomości i ekspresji kulturalnej. Po części nakładają się one również na inne kompetencje kluczowe (osobiste, społeczne, i w zakresie umiejętności uczenia się, obywatelskie, a nawet w pewnym stopniu cyfrowe). Oba przedstawione w projekcie obszary kompetencji można opisać jako wymagania ogólne.

3. Każde z wymagań ogólnych rozpisane jest na wymagania szczegółowe, przy czym proponuję dwa stopnie szczegółowości. W drugim stopniu szczegółowości wskazane są konkretne umiejętności, konkretna wiedza, a nawet konkretne operacje, które powinien wykonać uczeń. Ważne w tych zapisach jest jednak ścisłe ich powiązanie

\footnotetext{
${ }^{1}$ Biedrzycki K., 2019, Podstawa programowa do języka polskiego. Jaka może być? Jaka powinna być? Propozycja refleksji, w: Polonistyka i świat wartości. Edukacja polonistyczna jako wartość, Marzec-Jóźwik M., Karczewska A., Żurek S.J. (red.), Lublin, s. 71-89.

2 https://eur-lex.europa.eu/legal-content/PL/TXT/PDF/?uri=CELEX:32018H0604(01)\&from=EN (dostęp: 18.07.2020)
} 
z praktyką komunikacyjną lub kulturową. Na przykład typowo gramatyczny zapis przyjmuje następującą postać: [uczeń/uczennica] rozpoznaje części mowy (rzeczownik, czasownik, przymiotnik, przysłówek, liczebnik, zaimek, przyimek, spójnik, wykrzyknik, partykuła), potrafi określić ich znaczenie i funkcję w zdaniu oraz całej wypowiedzi, dostrzega możliwości stylistyczne i ekspresyjne w użyciu poszczególnych części mowy, ich ewentualnej wymiany lub pominięcia. Chodzi nie tylko o opanowanie wiedzy o częściach mowy, która miewa charakter abstrakcyjny, ale o jej wykorzystanie w komunikacji, zrozumienie funkcji części mowy i konsekwencji ich prawidłowego wykorzystywania. $\mathrm{Z}$ jednej strony chodzi o zagwarantowanie miejsca podstawowej wiedzy gramatycznej (ważnej jako dziedzina poznania, a także jako baza do nauki języków obcych), z drugiej - o jej wyraźnie pragmatyczne usytuowanie w dydaktyce.

4. Oprócz wymagań obejmujących umiejętności, które ma opanować uczeń, w projekcie podstawy programowej zawarte są też ogólne wskazania dla działań nauczyciela. Warto zwrócić uwagę, że mówi się $\mathrm{w}$ nich nie tyle o nauczaniu, ile o wspieraniu, zachęcaniu, inspirowaniu, pomaganiu, towarzyszeniu lub przewodniczeniu. Nauczyciel jest tu kimś, kto nie tylko tłumaczy i wymaga, ale nade wszystko jest osobą wspierającą w procesie poznania i ćwiczenia umiejętności.

5. Podstawa programowa dostosowana jest do obecnie funkcjonującej struktury szkolnictwa i obowiązujących (lub dostępnych, choć nieobowiązkowych) przedmiotów. Nie ma tu koncepcji innej organizacji edukacji.

6. Powyższy punkt ma znaczenie dlatego, że w przedstawionym projekcie przyjęte zostały dwie zasady dotyczące całości procesu dydaktycznego od przedszkola do matury: jest on integralny w sensie diachronicznym, to znaczy jeden dokument obejmuje rozwój kompetencji w ciągu wszystkich lat edukacji, zapisy na kolejnych etapach stanowią spójną całość, rozwinięcie i pogłębienie wymagań z wcześniejszych etapów; zarazem proces dydaktyczny w zakresie języka polskiego ma być uspójniony z całością procesu dydaktycznego, stąd zaznaczone zostały odniesienia do innych przedmiotów (łącznie z nadobowiązkowymi jak religia, etyka, wychowanie do życia w rodzinie czy język mniejszości narodowej), żeby kształcenie było integralne. Warto podjąć refleksję, jak łączyć treści programowe z różnych przedmiotów.

7. Projekt obejmuje całość edukacji, do matury. Ważne jest rozdzielenie wymagań na poziomie ponadpodstawowym. W liceum ogólnokształcącym i technikum na poziomie podstawowym kompetencje, w jakie jest wyposażany uczeń, muszą mieć charakter powszechny, 
to znaczy niespecjalistyczny. Przygotowujemy młodego człowieka, który bądź będzie studiował, bądź wykonywał pracę wymagającą średniego wykształcenia, a więc musi dysponować niezbędnymi kompetencjami komunikacyjnymi, a zarazem powinien mieć ogólną ogładę humanistyczną człowieka wykształconego powiązaną z aktywnym uczestnictwem w życiu kulturalnym. Wiedzę polonistyczną na wyższym poziomie, podłoże dla przygotowania do studiów humanistycznych, należy przekazywać uczniom wybierającym język polskie na poziomie rozszerzonym. Inne wymagania należy z kolei stawiać uczniom szkół branżowych pierwszego stopnia. To zróżnicowanie jest bardzo istotne.

8. Krótko zostały zasygnalizowane zasady sprawdzania kompetencji, nie tylko w postaci egzaminów. Ważna jest funkcja diagnostyczna badań. Każdy wynik powinien mieć formę opisową z wyeksponowaniem mocnych stron (co uczeń opanował) i wskazań do dalszej pracy. Każdy taki wynik powinien być uzupełniony przez opinię nauczyciela opartą na ciągłej obserwacji ucznia (wynik egzaminu lub badania diagnostycznego nie zawsze jest miarodajny, bo wpływają na niego różne czynniki deformujące). Kwestia egzaminów, badań kompetencji i ocen to jednak temat do osobnej dyskusji, jakkolwiek nie może być ona oderwana od debaty wokół podstawy programowej.

9. Łatwo zauważyć, ze w przedstawionym projekcie nie ma propozycji lektur. To lektury zawsze budzą najwięcej emocji, gdy się rozmawia o języku polskim w szkole. Tymczasem w moim przekonaniu najpierw trzeba ustalić czego, po co i jak uczyć, lektury to kwestia ważna, ale wtórna. Jedynie przedstawiłem wskazanie dotyczące postulowanej liczby lektur, zbliżonej do liczby lektur z podstawy programowej z 2008 roku. W istocie to ona i tak jest dosyć wysoka, jedna z najwyższych w Europie. Trzeba pamiętać, że zaangażowanie czytelnicze młodych ludzi wcale nie zależy od liczby lektur obowiązkowych, ale od liczby książek, które czytają poza obowiązkiem szkolnym.

10. Na koniec jedna uwaga wykraczająca poza tekst podstawy programowej. Dotychczasowe reformy zaskakiwały nauczycieli. Musieli oni szybko przestawiać swój sposób uczenia. Jakiekolwiek nowe zmiany musiałyby się wiązać z przygotowaniem nauczycieli, zwłaszcza że wymagania cywilizacyjne powodują, iż nauczanie języka polskiego (ale i innych przedmiotów) musi brać pod uwagę nowy kontekst zewnętrzny. Współczesny polonista musi być wyposażony nie tylko w wiedzę akademicką ze swojej dziedziny, ale i umiejętności związane z komunikacją medialną i cyfrową, powinien śledzić to, co się dzieje w kulturze i w ogóle humanistyce. Last but not least, musi mieć duże kompetencje psychologiczne, gdyż jak żaden 
inny nauczyciel uruchamia emocje, pracuje z emocjami. Do nowych wyzwań nauczyciela trzeba spokojnie przygotować. I nieustannie trzeba go wspierać. Dlatego - to utopijny projekt, ale niech będzie przedstawiony - w przyszłości system edukacyjny powinien każdemu nauczycielowi zagwarantować co siedem lat urlop naukowy (sabbatical) przeznaczony na dokształcenie na wyższej uczelni. Program studiów dla praktykujących nauczycieli powinien być dokładnie przemyślany, żeby pomagał nie tylko w uzupełnieniu wiedzy o jej najnowsze osiągnięcia, ale obejmowałby intensywne szkolenie metodyczne, technologiczne i psychologiczne.

Przedstawiam poniższy projekt do dyskusji. Oczywiście w pierwszym rzędzie kieruję go do środowiska polonistycznego. Dobrze by jednak było, gdyby został zaopiniowany też przez inne środowiska. Po pierwsze, przedmiot język polski tylko $\mathrm{w}$ niewielkim wymiarze jest przeznaczony dla przyszłych polonistów czy ogólniej - humanistów (z myślą o nich opracowana jest licealna podstawa programowa na poziomie rozszerzonym, poza tym oni sami przekraczają ramy programu szkolnego, konieczna jest indywidualna praca z nimi). Toteż bardzo ważna jest informacja, czego od nas - polonistów - oczekują wszyscy inni użytkownicy języka i uczestnicy kultury, akademicy z wszystkich innych dziedzin, pracodawcy, nauczyciele pozostałych przedmiotów szkolnych. Po drugie, wyjście poza krąg polonistyczny byłoby ważne, gdybyśmy wspólnie chcieli stworzyć wizję integralnego kształcenia w polskiej szkole, łączenia treści programowych, koordynowania pracy dydaktycznej.

\section{Podstawa programowa do języka polskiego}

W sytuacji, gdy obowiązek szkolny obejmuje dzieci od 7 roku życia, w podstawie programowej trzeba ściśle określić, z jakimi umiejętnościami dzieci rozpoczynają naukę w szkole. Podstawa programowa do wychowania przedszkolnego powinna być równie precyzyjna, jak podstawa programowa do kształcenia ogólnego w szkołach. Poniżej zapisane są wyłącznie wymagania dotyczące kompetencji polonistycznych (językowo-komunikacyjnych i literacko-kulturowych). Wprowadzone są jednak dopiski dotyczące konieczności koordynacji z innymi przedmiotami, w większości chodzi o przedmioty wprowadzane od IV klasy (lub nawet później), celem jest kształcenie u dzieci dyspozycji do tych przedmiotów. 
Edukacja przedszkolna (rozpoczynający edukację szkolną uczeń wykazuje się poniższymi kompetencjami)

I. Kompetencje językowo-komunikacyjne [uczeń/uczennica sprawnie - stosownie do możliwości rozwojowych - posługuje się językiem, rozumie skierowany do niego/niej przekaz, potrafi wyrazić własny przekaz w sposób jasny i zrozumiały dla odbiorcy, wyraża swoje myśli, mówi o emocjach, uczestniczy w komunikacji w grupie i szerszej społeczności]

Nauczyciel/nauczycielka:

1. Wspiera ucznia/uczennice w rozwoju umiejętności komunikacyjnych za pomocą różnych kodów;

2. Zachęca ucznia/uczennicę do wyrażania siebie, swoich potrzeb, emocji i myśli;

3. Pomaga w nawiązywaniu kontaktu z poznawanymi osobami - dorosłymi, dziećmi w grupie, wspiera w rozwiązywaniu konfliktów i pokazuje drogi budowania porozumienia;

4. Przewodniczy w poznawaniu nowych kodów komunikacyjnych, w tym języka pisanego.

\section{Uczeń/uczennica:}

1. Potrafi zrozumieć przekaz formułowany do niego/niej za pomocą rożnych znanych mu/jej kodów:

1.1. Z uwagą słucha osób, które do niego/niej mówią; [język mniejszości etnicznej]

1.2. Rozumie sens wypowiedzi, które są do niego/niej kierowane; [język obcy, język mniejszości etnicznej];

1.3. Rozumie sens piktogramów i emotikonów. [informatyka];

2. Coraz bardziej świadomie posługuje się językiem, w tym jego pisaną odmianą:

2.1. Zna litery, potrafi przeczytać krótkie zdania; [język mniejszości etnicznej]

2.2. Potrafi narysować proste figury i napisać wszystkie litery alfabetu;

2.3. Dzieli wyraz na sylaby. [język mniejszości etnicznej]

3. Jasno i ze świadomością tematu formułuje swoje wypowiedzi:

3.1. Zadaje pytania, gdy czegoś nie rozumie; [język mniejszości etnicznej]

3.2. Zwraca się bezpośrednio do rozmówcy; [język mniejszości etnicznej]

3.3. Prawidłowo artykułuje swoje wypowiedzi; [język obcy, język mniejszości etnicznej]

3.4. Zachowuje postawę ciała, mimikę i gestykulację odpowiednio do sytuacji;

3.5. Dostosowuje ton głosu do sytuacji.

4. Wykorzystuje język (i inne kody komunikacyjne) do przekazywania informacji, wyrażania siebie i funkcjonowania w społeczności (rodzinie, grupie rówieśniczej, przedszkolu lub szkole):

4.1. Wymienia imiona i nazwiska bliskich osób, zna adres, numer telefonu rodziców lub opiekunów, zna datę swoich urodzin i (lub) imienin;

4.2. Przedstawia nazwę miejscowości, w której mieszka, swojego państwa, stolicy; [wos]

4.3. Opowiada o swoich przeżyciach; [język mniejszości etnicznej] 
4.4. Opowiada o otaczającym go/ją świecie (przyroda, zjawiska atmosferyczne, relacje przestrzenne między przedmiotami); [przyroda, matematyka]

4.5. W zrozumiały sposób mówi o swoich potrzebach, uczuciach i poglądach na bliskie mu/jej sprawy; [język mniejszości etnicznej]

4.6. Uzasadnia swoje stanowisko w ważnych dla niego/niej sprawach; [język mniejszości etnicznej]

4.7. Rozwiązuje trudne sytuacje w grupie na drodze rozmowy; [wos, język mniejszości etnicznej]

4.8. Potrafi poinformować lekarza o swoim samopoczuciu oraz odpowiednie służby o niebezpiecznej sytuacji; [wos, język mniejszości etnicznej]

4.9. Za pomocą rysunku informuje o sprawach, które trudno mu/jej wyrazić za pomocą języka. [plastyka]

II. Kompetencje literackie i kulturowe [uczeń/uczennica rozumie dostosowane do wieku teksty kultury, których jest odbiorcą, zna kody, za pomocą których można je interpretować, potrafi o nich rozmawiać, dostrzega w nich emocje i inspiruje się nimi w refleksji o swoich doświadczeniach, odczytuje zawarte $w$ nich myśli, umieszcza je w różnych kontekstach, dzięki nim poznaje innych ludzi, potrafi z empatią mówić o ich doświadczeniu życiowym, emocjach, myślach i światopoglądzie]

\section{Nauczyciel/nauczycielka:}

1. Przewodniczy w poznawaniu przez ucznia/uczennice kodów, w których wyrażane są teksty kultury, i poznawaniu technik artystycznych;

2. Towarzyszy uczniowi/uczennicy w rozmowach o jego/jej przeżyciach związanych z odbiorem tekstów kultury, w tym o emocjach i myślach uruchamianych przez teksty, a związanych z doświadczeniem życiowym ucznia/uczennicy;

3. Inspiruje do własnej twórczości artystycznej ucznia/uczennicy.

\section{Uczeń/uczennica:}

1. Zna kody, za pomocą których wyrażone są różnego rodzaju teksty:

1.1. Słucha uważnie opowiadań, baśni, opowieści, wierszy i bajek, potrafi nazwać ich bohaterów i przedstawić zarys akcji, a także nazwać związane z utworem emocje; [język mniejszości etnicznej]

1.2. Rozróżnia prozę i wiersz, odróżnia utwór literacki od przekazu nieliterackiego;

1.3. Omawia ilustracje książkowe, porównuje przedstawienia graficzne z tekstem literackim; [plastyka, język mniejszości etnicznej]

1.4. Rozpoznaje na rysunkach i w innych formach graficznych postacie, przedmioty, elementy świata przyrody, relacje przestrzenne, emocje i inne znaczenia; [plastyka, przyroda, matematyka]

1.5. Z uwagą ogląda filmy i inne utwory audiowizualne, potrafi krótko przedstawić bohaterów i zarys akcji, a także związane z nimi emocje; [plastyka]

1.6. Ogląda przedstawienia teatralne ze znajomością konwencji i świadomością różnicy między prawdą a umowną kreacją sceniczną, potrafi krótko przedstawić bohaterów i zarys akcji, a także związane z nimi emocje;

1.7. Z uwagą słucha muzyki, w tym krótkich utworów muzyki poważnej, odróżnia muzykę instrumentalną od wokalnej; [muzyka]

1.8. Potrafi nazwać podstawowe instrumenty muzyczne; [muzyka]

1.9. Łączy muzykę $\mathrm{z}$ innymi formami wyrazu artystycznego (teatr, film, sztuki audiowizualne), potrafi krótko przedstawić rolę muzyki w utworze. [muzyka] 
2. Potrafi rozmawiać o emocjach, które w nim/niej budzą poznawane teksty, własnych przeżyciach związanych $z$ poznanymi tekstami, problemach życiowych, które odnajduje w tekstach, refleksjach, które budzą się w nim/niej po lekturze:

2.1. Rozróżnia postacie dobre i złe, potrafi przedstawić morał lub przesłanie utworu; [etyka, religia]

2.2. Rozmawia o bliskich mu/jej problemach, które dostrzega w poznanych utworach; [język mniejszości etnicznej]

2.3. Nazywa emocje, które w nim/niej budzą muzyka i dzieła plastyczne. [muzyka, plastyka]

3. Wyraża własne emocje za pomocą ekspresji artystycznej, zna różne formy twórczości, posługuje się rozmaitymi metodami artystycznymi:

3.1. Recytuje wiersze;

3.2. Śpiewa piosenki indywidualnie lub zbiorowo; [muzyka]

3.3. Bierze udział w przedstawieniach teatralnych, ze zrozumieniem wygłasza swoje kwestie, potrafi się posłużyć gestem, tańcem, i mimiką;

3.4. Wykorzystuje technikę audiowizualną do tworzenia krótkich utworów; [plastyka]

3.5. Stosuje różne techniki plastyczne, tworzy rysunki, wyklejanki, proste formy konstrukcyjne; [plastyka]

3.6. Za pomocą różnych form estetycznych (rysunek, opowiadanie, taniec, piosenka i inne) oddaje treść poznanych utworów (literackich, plastycznych, audiowizualnych, muzycznych, teatralnych) oraz związane z nimi emocje. [muzyka, plastyka]

Na początku pierwszej klasy każde dziecko przechodzi przez sprawdzian diagnostyczny kompetencji komunikacyjnych i kulturowych polegający na krótkiej rozmowie prowadzonej według wystandaryzowanego kwestionariusza obejmującego wymagania zapisane w podstawie programowej dla wychowania przedszkolnego. Wynik sprawdzianu jest opisowy, podkreśla się mocne strony rozwoju dziecka oraz obszary wymagające wzmożonej pracy. Przeznaczony jest dla nauczycielki/nauczyciela i rodziców. Rodzice na podstawie tego wyniku mają dostać informację, jak pracować z dzieckiem.

Edukacja wczesnoszkolna oczywiście musi być zintegrowana. Poniżej zapisane są wyłącznie wymagania dotyczące kompetencji polonistycznych (językowo-komunikacyjnych i literacko-kulturowych). Wprowadzone są dopiski dotyczące konieczności koordynacji z innymi przedmiotami, w większości chodzi o przedmioty wprowadzane od IV klasy, chodzi jednak o to, żeby w podstawie programowej precyzyjnie ująć, które umiejętności powinny nabyć dzieci w klasach I - III, żeby bez kłopotu zaczęły naukę nowych przedmiotów. Na etapie wczesnoszkolnym jest jednak bardzo ważne, żeby skoordynować naukę języka polskiego, języka mniejszości narodowych i etnicznych oraz języka obcego. 
Edukacja wczesnoszkolna (klasy 1 - 3) (kończący/-a trzecią klasę uczeń/uczennica wykazuje się następującymi kompetencjami)

I. Kompetencje językowo-komunikacyjne [uczeń/uczennica sprawnie - stosownie do możliwości rozwojowych - posługuje się językiem w mowie, piśmie oraz innych formach - w tym elektronicznych, rozumie skierowany do niego/niej przekaz, potrafi wyrazić własny przekaz w sposób jasny i zrozumiały dla odbiorcy, wyraża swoje myśli, mówi o emocjach, uczestniczy w komunikacji w grupie i szerszej społeczności]

\section{Nauczyciel/nauczycielka:}

1. Wspiera ucznia/uczennice $w$ uczestnictwie $w$ różnych formach komunikacji, zarówno bezpośredniej, jak publicznej;

2. Towarzyszy uczniowi/uczennicy w nawiązywaniu porozumienia, zwłaszcza w rozumieniu cudzej wypowiedzi;

3. Zachęca do wyrażania myśli i emocji oraz do ekspresji siebie;

4. Przewodniczy w poznawaniu zasad rządzących językiem i innymi kodami przekazywania myśli;

5. Inspiruje do twórczego posługiwania się językiem i innymi kodami;

6. Uczy tworzenia wypowiedzi $w$ różnych formach i towarzyszy uczniowi/uczennicy w rozwijaniu tych umiejętności.

\section{Uczeń/uczennica:}

1. Potrafi zrozumieć przekaz kierowany do niego/niej w bezpośredniej relacji oraz w przestrzeni publicznej:

1.1. Wykazuje się uwagą w kontaktach międzyludzkich;

1.2. Rozumie sens kierowanych do niego/niej wypowiedzi, potrafi go wyrazić własnymi słowami; [język obcy, język mniejszości etnicznej]

1.3. Posługuje się stosownym do wieku słownictwem potocznym, literackim i specjalistycznym, sukcesywnie rozszerza zasób słownictwa; [przyroda, matematyka, język mniejszości etnicznej]

1.4. Rozumie znaki graficzne (w tym znaki drogowe), napisy w miejscach publicznych, nazwy produktów w sklepie (etykiety, podpisy na półkach i inne);

1.5. Rozumie polecenia oraz treść zadań;

1.6. Czyta proste, dostosowane do wieku teksty; [język mniejszości etnicznej]

1.7. Wydobywa informacje z odbieranych wypowiedzi;

1.8. Korzysta z przeznaczonych dla dzieci słowników i leksykonów w postaci książkowej i cyfrowej. [informatyka]

2. Świadomie uczestniczy w komunikacji zarówno w bliskich relacjach osobistych (rodzina, grupa rówieśnicza), jak w sytuacjach publicznych i oficjalnych:

2.1. Aktywnie bierze udział $\mathrm{w}$ rozmowie na bliskie mu/jej tematy, rozumie, co inni do niego/niej mówią, odpowiada na pytania, z sensem kontynuuje wątek rozmowy; [język mniejszości etnicznej]

2.2. Skutecznie porozumiewa się $\mathrm{w}$ różnych sytuacjach społecznych (sklep, poczta, basen, boisko, plac zabaw i inne); [wos, język mniejszości etnicznej]

2.3. Kulturalnie zwraca się do rozmówcy; [język mniejszości etnicznej]

2.4. Dostosowuje ton głosu do sytuacji.

3. Wyraża swoje myśli, przekazuje informacje w taki sposób, że odbiorca rozumie jego/jej przekaz, intencje i emocje: 
3.1. Mówi na temat; [język mniejszości etnicznej]

3.2. Jasno wyraża swoje potrzeby; [język mniejszości etnicznej]

3.3. Nazywa swoje uczucia; [język mniejszości etnicznej]

3.4. Opowiada o różnych sytuacjach życiowych; [język mniejszości etnicznej]

3.5. Opisuje znany mu świat zewnętrzny. [język mniejszości etnicznej]

4. Świadomie posługuje się językiem jako kodem przekazywania myśli:

4.1. Odróżnia literę od głoski;

4.2. Prawidłowo artykułuje głoski, prawidłowo akcentuje wyrazy, stosuje odpowiednią intonację zdania; [język mniejszości etnicznej, język obcy]

4.3. Wyróżnia w tekście zdania;

4.4. Zna i stosuje podstawowe zasady ortograficzne, rozpoznaje wymianę głosek w wyrazach pokrewnych. [język mniejszości etnicznej]

5. Tworzy wypowiedzi w podstawowych formach:

5.1. Samodzielnie pisze proste zdania, przepisuje krótkie teksty, na końcu zdania stawia kropkę; [język mniejszości etnicznej]

5.2. Pod kierunkiem nauczyciela pisze notatkę z lekcji; [język mniejszości etnicznej]

5.3. Potrafi napisać życzenia, zaproszenie, zawiadomienie, list, e-mail, sms, kartkę z pozdrowieniami, notatkę w kronice, krótkie opowiadanie $\mathrm{z}$ własnego doświadczenia lub fikcyjne, opis [ponieważ szybkie zmiany technologiczne powodują zmiany form komunikowania się, nauczyciele powinni dostosowywać swoją pracę do potrzeb uczniów i aktualnych możliwości technologicznych, np. coraz mniejszą rolę odgrywają e-maile, ich miejsce zajmują inne sposoby porozumiewania się, które uczniowie opanowują poza szkołą, dlatego ten zapis powinien być weryfikowany]. [informatyka]

6. Stosuje różne formy przekazywania myśli:

6.1. Pisze ręcznie czytelnie z zastosowaniem zasad estetyki i kaligrafii;

6.2. Pisze proste teksty na nośnikach elektronicznych, edytuje teksty z zachowaniem zasad poprawności językowej, komunikatywności, czytelności i estetyki; [informatyka]

6.3. W pisanej wypowiedzi (zarówno pisanej ręcznie, jak na nośnikach elektronicznych) łączy język werbalny z językiem graficznym, dąży do jasności i ekonomii wyrazu. [informatyka]

II. Kompetencje literackie i kulturowe [uczeń/uczennica rozumie dostosowane do wieku teksty kultury, których jest odbiorcą, zna kody, za pomocą których można je interpretować, potrafi o nich rozmawiać, dostrzega w nich emocje i inspiruje się nimi w refleksji o swoich doświadczeniach, odczytuje zawarte w nich myśli, umieszcza je w różnych kontekstach, dzięki nim poznaje innych ludzi, potrafi z empatią mówić o ich doświadczeniu życiowym, emocjach, myślach i światopoglądzie]

\section{Nauczyciel/nauczycielka:}

1. Inspiruje ucznia/uczennice do udziału w kulturze przez lekturę utworów literackich i odbiór innych tekstów kultury;

2. Towarzyszy uczniowi/uczennicy w obcowaniu z tekstem;

3. W taki sposób przewodniczy w lekturze, żeby nauczyć rozumienia dzieła, wyszukiwania najważniejszych informacji, odczytywania przesłania;

4. Zachęca ucznia/uczennicę do poznawania dzieł z różnych dziedzin twórczości; 
5. Wzmacnia inwencję ucznia/uczennicy w jego/jej własnej twórczości artystycznej oraz w rozmawianiu o bliskich jemu/jej problemach, które znajdują wyraz w tekstach kultury.

\section{Uczeń/uczennica:}

1. Potrafi $z$ emocjonalnym zaangażowaniem odbierać tekst kultury w różnych dziedzinach, tworzywach i rodzajach. Rozumie sens zawarty w tekście, zwłaszcza jego przesłanie:

1.1. Słucha z uwagą opowieści i czytanych na głos utworów, potrafi przedstawić zarys fabuły, bohaterów, nazywa odczucia związane z poznanym tekstem; [język mniejszości etnicznej]

1.2. Słucha wierszy, rozumie zawarte $\mathrm{w}$ nich przesłanie, rozumie teksty piosenek; [muzyka]

1.3. Czyta utwory literackie przeznaczone dla dzieci, potrafi o nich rozmawiać, przedstawia imiona (nazwiska, role społeczne) bohaterów, cechy ich charakteru, perypetie;

1.4. Zaznacza w tekście fragmenty, którym nadaje szczególną rangę, uzasadnia swój wybór;

1.5. Potrafi posługiwać się podstawowym słownictwem umożliwiającym rozmowę o muzyce; [muzyka]

1.6. Nazywa emocje, które w nim/niej budzi utwór muzyczny - z repertuaru popularnego i klasycznego; [muzyka]

1.7. Z uwagą ogląda spektakle teatralne, filmy i utwory audiowizualne, omawia ich fabułę, prezentuje postaci, omawia rolę specyficznych dla poszczególnych form artystycznych rozwiązań.

2. Porównuje teksty z różnych dziedzin twórczości, dokonuje przekładu intersemiotycznego, wyraża siebie i swoje przeżycia za pomocą różnych technik artystycznych, włącza się we wspólnotowe (klasowe, szkolne, społeczne, narodowe) praktyki artystyczne:

2.1. Zestawia tekst literacki z ilustracją, omawia podobieństwa i różnice w przedstawieniu postaci i świata; [plastyka]

2.2. Przedstawia dostrzeżone $\mathrm{w}$ utworze myśli za pomocą dostępnych mu technik plastycznych (w tym elektronicznych); [plastyka, informatyka]

2.3. Dobiera muzykę (spośród znanych mu utworów) do poznanych tekstów, przedstawia utwory muzyczne, które mogą oddawać emocje wywoływane przez utwory literackie; [muzyka]

2.4. Recytuje wskazane przez nauczyciela wiersze, śpiewa piosenki; [muzyka]

2.5. Odgrywa scenki parateatralne przygotowane na podstawie poznanych utworów, posługuje się głosem, gestem, mimiką, tańcem w celu wyrażenia myśli dostrzeżonej w utworze;

2.6. W odgrywanych scenkach potrafi wyrażać emocje bohaterów i przedstawiać sposoby radzenia sobie z emocjami, zwłaszcza negatywnymi;

2.7. Zna słowa i melodię hymnu narodowego, potrafi go zaśpiewać; [muzyka, wos]

2.8. Potrafi opowiedzieć znane mu legendy i opowieści związane z kulturą i dziejami Polski. [historia]

3. Zainspirowany/zainspirowana lekturą potrafi mówić o poruszonych w tekstach problemach, własnych przeżyciach, emocjach i bliskich mu/jej zagadnieniach, poznane $w$ literaturze słownictwo i zawarte w tekstach kultury sposoby ukazywania świata wykorzystuje do własnego przedstawiania rzeczywistości:

3.1. Posługuje się słownictwem literackim czerpanym z przeczytanych utworów; [język mniejszości etnicznej] 
3.2. Rozmawia o zdarzeniach przedstawionych $\mathrm{w}$ poznanych utworach, zestawia je ze swoim doświadczeniem życiowym; [język mniejszości etnicznej]

3.3. Zainspirowany/zainspirowana utworami literackimi tworzy własne opowiadanie lub wiersz;

3.4. Wykorzystuje język utworów literackich do opisu swojej miejscowości, ciekawych obiektów architektury, okolicznej przyrody, do opowiadania o losach bliskich osób lub swojej społeczności; [plastyka, przyroda, historia, wos]

3.5. Zna słownictwo, za pomocą którego określa emocje, wartości, relacje międzyludzkie; [wos]

3.6. Wykorzystuje utwory artystyczne (literackie i inne) do rozmowy o doświadczeniach rodzinnych, uczuciach własnych i innych osób, przeszłości członków rodziny oraz marzeniach własnych i rówieśników; [wos, historia]

3.7. Za pomocą fabuł omawia przyczyny konfliktów, sposoby ich rozwiązywania, walkę dobra ze złem, wyraża empatię wobec bohaterów. [wos]

3.8. Potrafi opowiadać o utworach, które budzą jego/jej zainteresowanie. [muzyka, plastyka, informatyka]

Na początku czwartej klasy każde dziecko przechodzi przez sprawdzian diagnostyczny kompetencji komunikacyjnych i kulturowych. Sprawdzian ma dwa etapy. W pierwszym przeprowadza się krótką rozmowę według wystandaryzowanego kwestionariusza obejmującego wymagania zapisane $w$ podstawie programowej dla edukacji wczesnoszkolnej. W drugim dzieci piszą krótki test sprawdzający zrozumienie przeczytanego tekstu oraz stworzenia własnej wypowiedzi pisemnej. Wynik sprawdzianu jest opisowy, podkreśla sie mocne strony rozwoju dziecka oraz obszary wymagające wzmożonej pracy. Przeznaczony jest dla nauczycielek/nauczycieli wszystkich przedmiotów i dla rodziców. Rodzice na podstawie tego wyniku mają dostać informację, jak pracować z dzieckiem.

Bardzo ważna jest koordynacja kształcenia pomiędzy poszczególnymi przedmiotami. Podstawa programowa musi być spójna dla całej edukacji. Trzeba wprowadzić obowiązek koordynacji pracy między nauczycielami poszczególnych przedmiotów - równoległego wprowadzania podobnych treści. 

klasę uczeń wykazuje się następującymi kompetencjami)

I. Kompetencje językowo-komunikacyjne [uczeń/uczennica sprawnie - stosownie do możliwości rozwojowych - posługuje się językiem w mowie, piśmie oraz innych formach - w tym elektronicznych, rozumie skierowany do niego/niej przekaz, potrafi wyrazić własny przekaz w sposób jasny i zrozumiały dla odbiorcy, wyraża swoje myśli, mówi o emocjach, uczestniczy w komunikacji w grupie i szerszej społeczności, zna zasady rządzące językiem i wykorzystuje je do formułowania zrozumiałej, logicznej i precyzyjnej wypowiedzi]

\section{Nauczyciel/nauczycielka:}

1. Prowadzi ucznia/uczennicę w rozwoju umiejętności odbioru różnego rodzaju przekazów;

2. Kieruje pracą ucznia/uczennicy nad odczytywaniem znaczeń zawartych na różnych poziomach struktury wypowiedzi;

3. Wprowadza ucznia/uczennice w obszar zasad rządzących językiem polskim jako systemem i zachęca go/ją do samodzielnego odkrywania tych zasad w jego/jej praktyce językowej;

4. Wspiera ucznia/uczennice w rozwoju umiejętności językowych i skuteczności porozumiewania się;

5. Zapoznaje ucznia/uczennice $z$ różnymi formami przekazywania myśli i zachęca go/ją do tworzenia własnej wypowiedzi;

6. Uwrażliwia ucznia/uczennice na odpowiedzialność związaną z posługiwaniem się językiem i innymi kodami przekazywania informacji;

7. Zachęca ucznia/uczennicę do bogacenia słownictwa.

\section{Uczeń/uczennica:}

1. Rozwija umiejętność rozumienia drugiego człowieka, odbioru różnego rodzaju wypowiedzi sformułowanych w różnych kodach:

1.1. Rozumie odbierane komunikaty; [język obcy, wdż, język mniejszości etnicznej, edukacja dla bezpieczeństwa, wos, wf]

1.2. Sprawnie czyta teksty pisane; [język obcy, wdż, język mniejszości etnicznej]

1.3. Uważnie słucha wypowiedzi formułowanych ustnie; [język obcy, wdż, język mniejszości etnicznej, edukacja dla bezpieczeństwa, wos, wf]

1.4. Bierze udział w rozmowie i dyskusji, wsłuchuje się w wypowiedzi rozmówcy i dyskutantów, rozumie je, rzeczowo odnosi się do tych wypowiedzi; [język obcy, wdż, wos, język mniejszości etnicznej]

1.5. Potrafi odczytać istotne komunikaty wyrażone w sposób niewerbalny (gest, mimika, ton głosu i inne); [wdż, edukacja dla bezpieczeństwa, wf];

1.6. Rozumie język znaków graficznych; [plastyka, edukacja dla bezpieczeństwa]

1.7. Potrafi odczytać przekaz audiowizualny, rozumie sens obrazów, odczytuje znaczenia wynikające $\mathrm{z}$ relacji między wypowiedzią werbalną a obrazem; [informatyka, wos, edukacja dla bezpieczeństwa]

1.8. Rozróżnia typy tekstów: informacyjny, perswazyjny (w tym reklamowy), literacki (artystyczny); [plastyka, informatyka, wos]

1.9. Identyfikuje nadawcę wypowiedzi, odróżnia realnego autora od nadawcy wykreowanego (jawnego lub ukrytego); [historia]

1.10. Identyfikuje wpisanego w tekst odbiorcę wypowiedzi, odróżnia go od odbiorcy realnego. [historia] 
2. Rozumie przekaz zawarty $\mathbf{w}$ wypowiedzi drugiego człowieka, intencję nadawcy, logike tekstu, sens wyrażony przez strukture wypowiedzi, znaczenia wyrażone wprost i za pomocą rozmaitych tropów stylistycznych:

2.1. Określa temat i główną myśl wypowiedzi; [historia]

2.2. Potrafi zadać pytania do tekstu; [historia]

2.3. Sporządza plan odtwórczy wypowiedzi;

2.4. Potrafi odtworzyć wywód myślowy autora przekazu;

2.5. Wyciąga wnioski z przesłanek zawartych $\mathrm{w}$ tekście; [matematyka, historia, przyroda]

2.6. Wskazuje w tekście informacje wyrażone wprost i potrafi odczytać informacje wyrażone pośrednio; [historia]

2.7. Rozumie dosłowne i przenośne znaczenia występujące w wypowiedzi;

2.8. Odróżnia informacje ważne od drugorzędnych; [historia, wos, wdż]

2.9. Wskazuje miejsca dla niego/niej niezrozumiałe lub trudne, wyraża swoje uwagi lub wątpliwości, zadaje pytania uściślające; [historia, wos, wdż]

2.10. Rozpoznaje różnice między kłamstwem a fikcją; [historia, wos, wdż]

2.11. Potrafi wskazać źródła, w których może weryfikować wiarygodność przekazu; [informatyka, wos]

2.12. Potrafi zrozumieć znaczenie układu wypowiedzi, podziału na wstęp, rozwinięcie, zakończenie, puenty, konkluzji, w wypowiedzi pisemnej roli akapitów, w wypowiedzi mówionej postawy ciała, gestu, mimiki i pauz, w komunikacie audiowizualnym obrazu, dźwięku i montażu. [plastyka, informatyka, historia]

3. Zna podstawowe zasady systemu języka polskiego, swoją wiedze wykorzystuje w rozumieniu czyjejś wypowiedzi oraz tworzeniu własnego przekazu:

3.1. W czytanych tekstach rozpoznaje znaki interpunkcyjne: przecinek, dwukropek, średnik, cudzysłów, nawias - rozumie ich znaczenie;

3.2. Rozpoznaje w tekście funkcje składniowe słów w zdaniu (podmiot, orzeczenie, dopełnienie, przydawka, okolicznik), rozumie ich znaczenie w wypowiedzi; [język obcy, język mniejszości etnicznej]

3.3. Dostrzega logikę zawartą w składni zdania, tworzy prawidłowo zbudowane zdania o jasnym i wyraźnym znaczeniu; [matematyka, język obcy, język mniejszości etnicznej]

3.4. Rozróżnia zdania pojedyncze nierozwinięte i rozwinięte, dostrzega różnice zawartych w nich znaczeń; [język obcy, język mniejszości etnicznej]

3.5. Rozpoznaje zdania złożone, odczytuje relacje między zdaniami składowymi, w samodzielnym tworzeniu tekstu prawidłowo stosuje przecinki, które pozwalają na tworzenie zdań spójnych logicznie; [język obcy, język mniejszości etnicznej]

3.6. Potrafi rozpoznać i właściwie wprowadzić do własnej wypowiedzi równoważnik zdania, rozumie logiczne oraz stylistyczne konsekwencje stosowania tej formy;

3.7. Rozpoznaje części mowy (rzeczownik, czasownik, przymiotnik, przysłówek, liczebnik, zaimek, przyimek, spójnik, wykrzyknik, partykuła), potrafi określić ich znaczenie i funkcję w zdaniu oraz całej wypowiedzi, dostrzega możliwości stylistyczne i ekspresyjne w użyciu poszczególnych części mowy, ich ewentualnej wymiany lub pominięcia; [język obcy, język mniejszości etnicznej]

3.8. Stosuje prawidłowe formy przypadków, liczb, osób, czasów i rodzajów gramatycznych w celu poprawnego i jasnego, a także poprawnego stylistycznie sformułowania wypowiedzi, wykorzystuje wiedzę o tematach fleksyjnych wyrazów odmiennych jako podstawę zasad ortograficznych; [język obcy, język mniejszości etnicznej] 
3.9. Potrafi poprawnie stopniować przymiotniki i przysłówki, zna konsekwencje znaczeniowe i ekspresyjne użycia poszczególnych stopni; [język obcy, język mniejszości etnicznej]

3.10. Rozróżnia zdania oznajmujące, pytające i rozkazujące, rozumie ich znaczenie oraz funkcje $\mathrm{w}$ wypowiedzi, poprawnie je stosuje $\mathrm{w}$ tekście pisanym oraz wypowiedzi ustnej, właściwie z nich korzysta w rozmowie i dyskusji, w zapisie stosuje znaki zapytania i wykrzykniki; [język obcy, język mniejszości etnicznej]

3.11. W tworzeniu i redagowaniu wypowiedzi potrafi wprowadzać różne typy zdań zależnie od kontekstu i celu, umie zamieniać zdania złożone na pojedyncze i na odwrót, a także zamieniać równoważniki zdań na zdania i (jeśli to możliwe) na odwrót, prawidłowo stosuje reguły interpunkcji w poszczególnych typach wypowiedzeń. [język obcy, język mniejszości etnicznej]

4. Zna różne odmiany języka polskiego, potrafi je rozpoznać i sformulować wypowiedź zależną od sytuacji, rozumie zasady formułowania poprawnej wypowiedzi i stosuje je w kontakcie z drugim człowiekiem:

4.1. Rozróżnia oficjalną i nieoficjalną sytuację wypowiedzi, rozumie wpływ kontekstu na znaczenie wypowiedzi, dostosowuje swoją wypowiedź do sytuacji, stosuje zasady etykiety; [wos, wdż, , edukacja dla bezpieczeństwa, wf]

4.2. W wypowiedzi stosuje odpowiednią kompozycję, która jest podporządkowana założonemu celowi, tekst pisany dzieli na akapity, stosuje podziały tematyczne fragmentów tekstu, zachowuje logikę wywodu;

4.3. Stosuje zasady ortografii i prawidłowej artykulacji fonetycznej, dostrzega różnice w wymowie i pisowni samogłosek ustnych i nosowych, spółgłosek twardych i miękkich, dźwięcznych i bezdźwięcznych, potrafi właściwie stosować pisownię „nie” z rzeczownikami, przymiotnikami i czasownikami, prawidłowo zapisuje nazwy własne i nazwy pospolite;

4.4. Umiejętnie redaguje wypowiedź pisemną, pisze czytelnie z zachowaniem zasad kaligrafii, w tekście pisanym na nośnikach elektronicznych wykorzystuje odpowiednią czcionkę, zachowuje odstępy. [informatyka]

5. Tworzy samodzielne wypowiedzi we wskazanych gatunkach, uwzględnia rolę odbiorcy:

5.1. Samodzielnie tworzy notatkę z lekcji; [wszystkie przedmioty]

5.2. Tworzy wypowiedzi pisemne w następujących formach gatunkowych: opowiadanie z dialogiem (twórcze i odtwórcze, dotyczące prawdziwych zdarzeń i oparte na fikcji), pamiętnik, dziennik, blog, list oficjalny, e-mail oficjalny, sprawozdanie, opis, ogłoszenie; [informatyka]

5.3. Potrafi wygłosić kilkuminutową samodzielną monologową wypowiedź ustną na interesujący go/ją temat, potrafi uzasadnić swoją opinię, dobiera właściwe argumenty; [język obcy, język mniejszości etnicznej]

5.4. Przedstawia krótką samodzielnie przygotowaną prezentację multimedialną na ważny dla niego/niej temat. [informatyka]

6. Odpowiedzialnie posługuje sie językiem i innymi kodami komunikacji, właściwie stosuje je $w$ relacjach $\mathrm{z}$ innymi:

6.1. Stosuje zasady etyki wypowiedzi, odróżnia prawdę od kłamstwa, wymianę opinii od agresji, racjonalną argumentację od wypowiedzi emocjonalnej; [wos, wdż, etyka, religia, edukacja dla bezpieczeństwa, wf]

6.2. Prawidłowo i odpowiedzialnie ( $\mathrm{z}$ zastosowaniem zasad n-etykiety) posługuje się formami komunikacji na nośnikach elektronicznych, wykorzystuje w nich ogólne zasady dotyczące rozmowy, dyskusji, formułowania własnej opinii, uzasadniania swojego zdania, potrafi roz- 
różnić zasady rządzące wypowiedziami tradycyjnymi i na nośnikach elektronicznych; [informatyka, etyka, religia]

6.3. Potrafi rozwijać umiejętności językowe w pracy w grupie, tworzy więzi społeczne, wyraża własne potrzeby, uczucia, opisuje swoją pozycję w rodzinie, szkole i grupie przyjacielskiej, otwiera się na innych ludzi, próbuje ich zrozumieć; [wos, wdż]

6.4. Wykorzystuje sprawność w posługiwaniu się językiem w rozwiązywaniu konfliktów. [wos, wdż, edukacja dla bezpieczeństwa, wf]

7. Rozwija słownictwo, posługuje się językiem jako plastycznym narzedziem komunikacji, opisu świata, wyrażenia samego/samej siebie i porozumienia $z$ innymi:

7.1. Posługuje się coraz bogatszym słownictwem w różnych dziedzinach życia (w tym naukowych), potrafi mówić o swoich zainteresowaniach z wykorzystaniem urozmaiconego słownictwa, wykorzystuje synonimy i antonimy, wskazuje podobieństwa brzmieniowe i znaczeniowe słów, dostrzega różnice słów podobnie brzmiących; [wszystkie przedmioty]

7.2. Potrafi wskazać temat słowotwórczy i formant oraz wyjaśnić modyfikację znaczeniową, którą wprowadza formant, tworzy rodzinę wyrazów, wykorzystuje wiedzę z zakresu słowotwórstwa do bogacenia leksyki; [język obcy, język mniejszości etnicznej]

7.3. Posługuje się słownictwem, które umożliwia mu/jej mówienie o własnej tożsamości narodowej i społecznej, opisywanie rzeczywistości, wyrażanie emocji; [historia, wos, wdż, język mniejszości etnicznej]

7.4. Wykorzystuje różne źródła do bogacenia słownictwa - słowniki (tradycyjne i elektroniczne), dzieła literackie, artykuły prasowe i popularnonaukowe, sprawozdania sportowe i recenzje artystyczne, język potoczny, język regionalny i inne. [informatyka, plastyka, muzyka, wf, inne przedmioty]

II. Kompetencje literackie i kulturowe [uczeń/uczennica rozumie dostosowane do wieku teksty kultury, których jest odbiorcą, zna kody, za pomocą których można je interpretować, potrafi o nich rozmawiać, dostrzega w nich emocje i inspiruje się nimi w refleksji o swoich doświadczeniach, odczytuje zawarte $w$ nich myśli, umieszcza je w różnych kontekstach, dzięki nim poznaje innych ludzi, potrafi z empatią mówić o ich doświadczeniu życiowym, emocjach, myślach i światopoglądzie]

Nauczyciel/nauczycielka:

1. Wprowadza ucznia/uczennicę w dziedzinę kultury;

2. Zachęca ucznia/uczennicę do samodzielnej lektury;

3. Towarzyszy uczniowi/uczennicy w lekturze dzieła literackiego i innego tekstu kultury, inspiruje go/ją do samodzielnego odczytania utworu, zachęca do odbioru w kontekście własnego doświadczenia ucznia/uczennicy;

4. Odkrywa przed uczniem/uczennicą świat konwencji artystycznych, poetyki i wartościowania estetycznego, zachęca go/ją do własnej oceny dzieła i uzasadnienia sformułowanego sądu;

5. Wspiera ucznia/uczennice $\mathbf{w}$ wykorzystywaniu środków artystycznych w ekspresji siebie i w dialogu z odbieranymi tekstami kultury.

\section{Uczeń/uczennica:}

1. W twórczy sposób odczytuje dzieła literackie i inne teksty kultury, ma świadomość siebie jako aktywnego odbiorcy, potrafi zrozumieć 
własne emocje, $\mathrm{z}$ jakimi odbiera tekst, umieszcza tekst w obszarze swojego doświadczenia, a także poszukuje odniesień uniwersalnych:

1.1. Przedstawia swoje wrażenia odbiorcze po lekturze dzieła literackiego lub poznaniu utworu z innych dziedzin twórczości; [plastyka, muzyka, informatyka]

1.2. Mówi o tym, co w dziele go/ją zainteresowało lub co stanowiło dla niego/niej trudność; [plastyka, muzyka, informatyka]

1.3. Odnosi się do swoich oczekiwań odbiorczych dotyczących treści, kreacji bohaterów, konwencji literackiej lub artystycznej; [plastyka, muzyka, informatyka]

1.4. Opowiada o odczuciach, które budzi utwór; [plastyka, muzyka, informatyka,wdż]

1.5. Rozumie motywy postępowania bohaterów, rozpoznaje ich emocje, odtwarza ich doświadczenia życiowe, charakteryzuje ich, ocenia - uzasadnia swoją opinię; [wdż, wos. historia]

1.6. Zestawia sytuację bohaterów z własnym doświadczeniem lub z wiedzą o świecie; [wdż, wos, historia, edukacja dla bezpieczeństwa]

1.7. Wskazuje obecne w klasycznych utworach literackich i innych tekstach kultury (w tym w mitach) ponadczasowe treści dotyczące człowieka; [religia]

1.8. Wyszukuje w rzeczywistości pozaszkolnej obecność ponadczasowych motywów kulturowych (mitologicznych, literackich, artystycznych). [plastyka, muzyka, historia, religia]

2. Rozpoznaje konwencje artystyczne, dokonuje odbioru na różnych poziomach struktury tekstu, przedstawia pozycje interpretacji dzieła, szuka uzasadnienia dla swojej interpretacji $w$ analizie tekstu:

2.1. Omawia akcję utworu, wyodrębnia poszczególne wydarzenia oraz wątki;

2.2. Odróżnia fikcję artystyczną od rzeczywistości oraz fikcję artystyczną od fantastyki;

2.3. Dostrzega w dziele znaczenia dosłowne i znaczenia przenośne;

2.4. Formułuje propozycję odczytania przesłania dzieła, przedstawia argumenty, za pomocą których może ją uzasadnić;

2.5. Konfrontuje własną propozycję odczytania z propozycjami innych osób w klasie, zestawia argumenty, uzasadnia przyjęcie lub odrzucenie opinii kolegów/koleżanek; [wos, wdż]

2.6. Przedstawia swoistość poznanego dzieła, dziedziny twórczości, do której ono należy, jego tworzywa, konwencji, która została wykorzystana; [plastyka, muzyka, informatyka]

2.7. Omawia specyfikę językową przeczytanego dzieła literackiego, zwraca uwagę na słownictwo, sposób budowania zdań, podobieństwa i różnice wobec języka, którym na co dzień sam/sama się posługuje;

2.8. Mówi o ewentualnych trudnościach językowych, rozwiązuje je, odwołując się do swojej kompetencji językowej (np. wiedzy z zakresu gramatyki, zwłaszcza słowotwórstwa) lub szukając wyjaśnień w słownikach i innych źródłach;

2.9. Odczytuje znaczenia słów i zdań, wykorzystuje je jako klucz do zrozumienia utworu, odnosi się do swoich kompetencji językowych;

2.10. Rozpoznaje w utworze literackim przenośnię, porównanie, epitet, wyraz dźwiękonaśladowczy - objaśnia ich rolę w tekście, celowość użycia, także efekty estetyczne i semantyczne, które dzięki nim można osiągnąć;

2.11. W interpretacji utworu uwzględnia jego budowę, kompozycję, sposób budowania fabuły lub obrazu.

3. Zna podstawowe pojęcia z zakresu poetyki i estetyki oraz wykorzystuje je w opisie dzieła i uzasadnieniu własnego wartościowania utworu: 
3.1. Potrafi wskazać i omówić występujące w wierszu wers, zwrotkę (strofę), rym, rytm, refren, rozpoznaje wiersz rymowany i nierymowany;

3.2. Porównuje wiersz z piosenką, wskazuje to, co je łączy (rytm) i co dzieli (warstwa słowna - warstwa melodyczna), omawia różnice tekstu wydrukowanego, recytowanego i śpiewanego; [muzyka]

3.3. Omawia rolę rytmu, harmonii i symetrii w twórczości muzycznej, literackiej, artystycznej oraz w świecie pozaartystycznym; [muzyka, plastyka, matematyka, fizyka, biologia, technika, wf]

3.4. Potrafi nazwać swoje emocje wywołane przez muzykę; [muzyka]

3.5. Przedstawia ulubione gatunki muzyczne, uzasadnia wybór; [muzyka]

3.6. Rozpoznaje gatunki literackie: powieść (obyczajowa, fantastyczna, przygodowa), opowiadanie, baśń, legenda, mit, bajka, fraszka, piosenka, przysłowie, aforyzm, przypowieść, pamiętnik, dziennik, komiks;

3.7. Potrafi omówić przenikanie się gatunków, zwłaszcza we współczesnej literaturze;

3.8. Omawia elementy spektaklu teatralnego (gra aktorska, reżyseria, scenografia, kostiumy, charakteryzacja), omawia ich rolę w budowaniu znaczeń przedstawienia;

3.9. Bierze udział w przygotowanym w szkole spektaklu, potrafi zinterpretować odtwarzaną postać, uzasadnić jej motywy postępowania; [wdż]

3.10. Przedstawia elementy dzieła filmowego (reżyseria, obraz, gra aktorska, montaż), omawia ich rolę w budowaniu atmosfery i znaczeń oraz w wywoływaniu emocji;

3.11. Rozpoznaje różne rodzaje filmu (fabularny, dokumentalny, animowany), wskazuje różnice między nimi, przedstawia przykłady;

3.12. Porównuje obejrzany spektakl teatralny z dziełami literackimi i filmami, omawia różnice estetyczne oraz w przypadku adaptacji - różnice znaczeniowe;

3.13. Prezentuje ulubione gatunki filmowe, uzasadnia swoją opinię;

3.14. Opisuje dzieło sztuki (obraz, rzeźba, grafika, fotografia), wykorzystuje możliwie bogate słownictwo, przedstawia propozycję odczytania dzieła; [plastyka]

3.15. Porównuje dzieło sztuki z dziełem z innej dziedziny twórczości, w którym pojawia się podobny temat lub motyw, wskazuje różnice wynikające z tworzywa utworu; [plastyka, muzyka, informatyka]

3.16. Opisuje dzieło sztuki architektonicznej, ogród, pejzaż, porównuje ich wygląd z przedstawieniem w sztuce, wykorzystuje możliwie bogate słownictwo; [plastyka, technika]

3.17. Prezentuje ulubione dziedziny twórczości artystycznej - uzasadnia swoją opinię; [plastyka, muzyka]

3.18. Porównuje literackie i artystyczne przedstawienie świata z przedstawieniem naukowym. [fizyka, biologia, chemia, geografia]

4. Wykorzystuje formy ekspresji artystycznej $\mathbf{w}$ dialogu $\mathbf{z}$ poznanymi tekstami kultury:

4.1. Przedstawia poznane dzieło literackie lub artystyczne za pomocą opowiadania, streszczenia, opisu lub prezentacji; [plastyka, muzyka, informatyka]

4.2. Interpretuje głosowo fragmenty prozy i wiersze;

4.3. Bierze udział w przygotowanym w szkole spektaklu, potrafi zinterpretować odtwarzaną postać, uzasadnić jej motywy postępowania; [wdż, etyka, religia]

4.4. Wykorzystuje różne formy literackie lub artystyczne (opowiadanie, wiersz, filmik, clip, przedstawienie, recytacja, śpiew itd.) w celu przedstawienia własnej autorskiej interpretacji poznanego dzieła z różnych dziedzin twórczości; [plastyka, muzyka, technika, informatyka]

4.5. Zainspirowany/zainspirowana dziełem literackim lub artystycznym rozmawia o ważnych sprawach dotyczących jego/jej doświadczenia 
(rodzina, szkoła, problemy dojrzewania, emocje), światopoglądu, moralności (wybory dobra lub zła), historii, problemów społecznych i narodowych, innych spraw dla niego/niej istotnych, potrafi mówić o swojej identyfikacji rodzinnej, lokalnej, narodowej, państwowej, ogólnoludzkiej, znajduje sposoby zrozumienia innych. [historia, wos, wdż, etyka, religia, edukacja dla bezpieczeństwa ]

Na początku siódmej klasy każda uczennica i każdy uczeń przechodzi przez sprawdzian diagnostyczny kompetencji komunikacyjnych i kulturowych. Sprawdzian ma dwa etapy. W pierwszym uczniowie piszą test sprawdzający zrozumienie różnego rodzaju tekstów oraz umiejętność stworzenia własnej wypowiedzi pisemnej. W drugim przeprowadzona jest rozmowa na przygotowany przez ucznia/ uczennicę temat. Uczniowie prezentują wynik własnej pracy inspirowanej tekstami kultury $w$ wybranej formie (od prezentacji multimedialnej po napisany przez siebie wiersz) i opowiadają o własnych zainteresowaniach lub podejmowanych $w$ pracy problemach. Wynik sprawdzianu jest opisowy, podkreśla się mocne strony rozwoju uczennicy/ucznia oraz obszary wymagające wzmożonej pracy. Przeznaczony jest dla nauczycielek/nauczycieli wszystkich przedmiotów i dla rodziców.

Wraz z VIII klasą kończy się etap jednolitej, powszechnej edukacji. Wymagania dotyczą wszystkich uczniów, a więc zarówno przyszłych profesorów, jak robotników. Nie mogą zatem być zbyt ambitne, muszą być dostosowane do możliwości również uczniów z trudem przyswajających wiedzę, zarazem jednak powinny stanowić minimum umiejętności, wiedzy i kompetencji społecznych niezbędne do rozumienia kodu kulturowego, prawidłowego funkcjonowania $\mathrm{w}$ społeczeństwie, w tym na rynku pracy. Dla uczniów zdolnych i szczególnie zainteresowanych przedmiotem powinien być przygotowany indywidualny tryb pracy, im mają służyć konkursy, jak również rozbudowane projekty. Również indywidualny charakter musi mieć praca z uczniami wykazującymi trudności w nauce. To oczywiście dotyczy wszystkich etapów, jest jednak szczególnie istotne w końcowych klasach szkoły podstawowej. 


\section{Szkoła podstawowa III etap edukacyjny (klasy 7 - 8) (kończący szkołę podstawową uczeń wykazuje się następującymi kompetencjami)}

I. Kompetencje językowo-komunikacyjne [uczeń/uczennica sprawnie - stosownie do możliwości rozwojowych - posługuje się językiem w mowie, piśmie oraz innych formach - w tym elektronicznych, rozumie skierowany do niego/niej przekaz, potrafi wyrazić własny przekaz w sposób jasny i zrozumiały dla odbiorcy, wyraża swoje myśli, mówi o emocjach, uczestniczy w komunikacji w grupie i szerszej społeczności]

\section{Nauczyciel/nauczycielka:}

1. Zachęca ucznia/uczennicę do samodzielnego poszukiwania informacji w różnych źródłach, towarzyszy mu/jej w krytycznej weryfikacji źródeł i analizie informacji;

2. Inspiruje do obserwacji języka i wyróżniania w nim różnych odmian;

3. Prezentuje różne formy wypowiedzi i wspiera ucznia/uczennice w tworzeniu samodzielnych wypowiedzi w poznanych formach;

4. Zachęca ucznia/uczennice do bogacenia słownictwa;

5. Towarzyszy uczniowi/uczennicy w refleksji nad odpowiedzialnością za przekaz i wspiera go/ją w tworzeniu nakierowanej etycznie, estetycznie i etykietalnie wypowiedzi.

\section{Uczeń/uczennica:}

1. Potrafi samodzielnie wyszukiwać informacje w różnych źródłach, hierarchizować je, krytycznie analizować treść i formę przekazu, odczytywać zawarte w nim intencje, dostrzegać funkcje tekstu:

1.1. Samodzielnie dociera do potrzebnych mu informacji - w książkach, prasie, mediach elektronicznych, a także bezpośrednio u kompetentnych osób; [informatyka, wos, historia, biologia, geografia, chemia, fizyka]

1.2. Świadomie, odpowiedzialnie, selektywnie korzysta ze źródeł informacji, potrafi ocenić ich wiarygodność, potrafi w wiarygodnych źródłach zweryfikować prawdziwość informacji; [informatyka, wdż, wos, historia, edukacja dla bezpieczeństwa, biologia, geografia, chemia, fizyka]

1.3. Ze zrozumieniem odbiera komunikaty pisane i mówione, w tym przekazywane za pomocą nośników elektronicznych - właściwie dekoduje informacje przekazane werbalnie, niewerbalnie, za pomocą dźwięku i obrazu; [informatyka, historia, języki obce, język mniejszości etnicznej]

1.4. Przedstawia treści wypowiedzi w takim porządku, w jakim występują w tekście; [języki obce, język mniejszości etnicznej]

1.5. Wyszukuje i wskazuje $\mathrm{w}$ wypowiedzi informacje, które są w niej zawarte; [języki obce, język mniejszości etnicznej, historia]

1.6. Potrafi zacytować właściwy fragment wypowiedzi zawierający odpowiednią informację; [języki obce, język mniejszości etnicznej, historia, wos]

1.7. Porządkuje informacje zależnie od ich wagi i funkcji w przekazie; [historia, wos]

1.8. Odróżnia informację od opinii; [historia, wos, wdż]

1.9. Rozpoznaje wypowiedź argumentacyjną, wskazuje w niej tezę lub hipotezę, argumenty, wnioski; [historia, wos, matematyka]

1.10. Rozpoznaje wypowiedzi o charakterze emocjonalnym i perswazyjnym, odróżnia je od wypowiedzi informacyjnych; [historia, wos, wdż] 
1.11. Dostrzega intencję zawartą w wypowiedzi - aprobatę, krytykę, ironię, negację, prowokację; [historia, wos, edukacja dla bezpieczeństwa]

1.12. Dostrzega agresję i manipulację w wypowiedziach je zawierających. [historia, wos, wdż, edukacja dla bezpieczeństwa]

2. Wyróżnia różne odmiany w ramach języka polskiego, posługuje się językiem ogólnonarodowym, potrafi wyrazić myśl w różnych znanych mu/jej stylach:

2.1. Odróżnia style wypowiedzi: potoczny, urzędowy, artystyczny i naukowy, a także potrafi dostosować styl wypowiedzi do sytuacji komunikacyjnej; [języki obce, język mniejszości etnicznej, historia, wos, edukacja dla bezpieczeństwa]

2.2. Rozpoznaje cechy języka swojego regionu lub grupy społecznej (w tym języka uczniowskiego), zna granice stosowania poszczególnych odmian języka, potrafi znaleźć odpowiedniki słów z języka o ograniczonym zasięgu w języku ogólnonarodowym; [język mniejszości etnicznej]

2.3. Rozróżnia normę językową wzorcową oraz użytkową i stosuje się do nich; [język mniejszości etnicznej]

2.4. Sprawnie posługuje się oficjalną odmianą polszczyzny.

3. Umiejętnie tworzy wypowiedzi ustne i pisemne, także przy użyciu pozajęzykowych środków przekazu:

3.1. Tworzy spójne wypowiedzi ustne, monologowe i dialogowe, dostosowane do sytuacji, słuchaczy, stylu wypowiedzi; [języki obce, język mniejszości etnicznej]

3.2. Stawia jasny cel swojej wypowiedzi (zainteresowanie odbiorcy, przekazanie informacji, przekonanie odbiorcy, wyrażenie emocji), formułuje tezę, hipotezę lub temat wypowiedzi, dobiera argumenty i przykłady, formułuje konkluzję, stosuje formę wołacza w celu osiągnięcia odpowiedniego efektu retorycznego; [historia, wos, wdż]

3.3. W rozmowie i dyskusji uważnie słucha interlokutorów i adwersarzy, próbuje zrozumieć ich racje i intencje, potrafi przedstawić treść ich wypowiedzi, jasno przedstawia swoje stanowisko, nie przypisuje rozmówcom treści, których nie wypowiedzieli, nie stosuje argumentów ad personam; [języki obce, język mniejszości etnicznej, historia, wos, wdż]

3.4. W wypowiedzi ustnej dba o odpowiednią modulację głosu, postawę, mimikę, język ciała;

3.5. Korzysta z elektronicznych nośników informacji w celu formułowania własnego przekazu, łączy umiejętności językowe z kompetencją korzystania z mediów cyfrowych, ma świadomość roli przekaźnika w formułowania komunikatu, funkcji obrazu, dźwięku, sposobu percepcji przez odbiorcę; [informatyka, wos, wdż]

3.6. Tworzy wypowiedź pisemną w formie rozprawki, stawia tezę lub hipotezę, dowodzi swojej tezy, prowadzi logiczny wywód argumentacyjny, dobiera argumenty i przykłady, formułuje konkluzję zamykającą tekst; [języki obce, język mniejszości etnicznej, historia, matematyka]

3.7. Tworzy urozmaicone kompozycyjnie i fabularnie opowiadanie z dialogiem - oparte na fikcji lub dotyczące rzeczywistego wydarzenia, rozpoczyna w sposób mogący zaintrygować czytelnika, przedstawia i zarysowuje sylwetki postaci (wygląd, charakter), rozwija akcję do punktu kulminacyjnego, formułuje zamykającą tekst konkluzję;

3.8. Potrafi napisać sprawozdanie $\mathrm{z}$ wydarzenia, w którym brał/brała udział; [języki obce, język mniejszości etnicznej, wos]

3.9. Potrafi stworzyć charakterystykę postaci literackiej, filmowej lub rzeczywistej, uwzględnia motywy postępowania, wykazuje się empatią; [wdż] 
3.10. Pisze podanie, życiorys, CV, list motywacyjny, instrukcję zgodnie $\mathrm{z}$ wymaganiami form, konwencją i kontekstem sytuacyjnym. [języki obce, język mniejszości etnicznej, wos]

4. Wykorzystuje wiedze o języku w formułowaniu poprawnej i skutecznej komunikacyjnie wypowiedzi:

4.1. Szyk wyrazów w wypowiedzi i szyk zdań składowych w zdaniach złożonych dostosowuje do wagi, jaką nadaje przekazywanym informacjom; [języki obce, język mniejszości etnicznej]

4.2. Zgodnie z celem wypowiedzi korzysta ze zdań złożonych lub pojedynczych, form strony czynnej lub strony biernej, form bezosobowych czasowników lub imiesłowów; [języki obce, język mniejszości etnicznej]

4.3. Potrafi prawidłowo wprowadzać do wypowiedzi mowę niezależną i mowę zależną; [języki obce, język mniejszości etnicznej]

4.4. Poprawnie, zgodnie z logiką wypowiedzi stosuje interpunkcję, wykorzystuje w tym celu wiedzę o składni. [języki obce, język mniejszości etnicznej]

5. Umiejętnie korzysta $\mathrm{z}$ własnego zasobu słownikowego, ustawicznie wzbogaca swoją leksykę:

5.1. Stosuje możliwie bogate słownictwo dotyczące dziedzin jego/jej zainteresowań, sportu, rozrywki, codziennego doświadczenia, dojrzałości emocjonalnej, rodziny, własnego środowiska, polityki, narodu, światopoglądu, nauki, techniki, planowanego zawodu, planowanej przyszłości; [języki obce, wf, wos, plastyka, muzyka, wdż, edukacja dla bezpieczeństwa, biologia, chemia, fizyka, geografia]

5.2. Rozumie znaczenia zawarte w związkach frazeologicznych i świadomie z nich korzysta we własnych wypowiedziach. [języki obce, język mniejszości etnicznej]

6. Odpowiedzialnie i z szacunkiem wobec odbiorcy posługuje się językiem i wszelkimi formami komunikacji:

6.1. Przestrzega zasad etyki mowy w różnych sytuacjach komunikacyjnych, jest świadomy/świadoma efektu stosowania mowy nienawiści, wykorzystywania nacechowania emocjonalnego wypowiedzi, manipulacji, obrażania, stosowania wulgaryzmów, rozpowszechniania nieprawdziwych informacji, zawstydzania innych, stawiania ich w kłopotliwych sytuacjach, publikowania kompromitujących obrazów w mediach elektronicznych; [informatyka, wos, wdż, religia, etyka, edukacja dla bezpieczeństwa, wf]

6.2. Stosuje zasady etykiety językowej oraz etykiety $\mathrm{w}$ elektronicznych środkach komunikacji, wie, jak się zwracać do odbiorcy zależnie od sytuacji, relacji między osobami, które się komunikują, zna konsekwencje stosowania formuł niewłaściwych lub obraźliwych. [informatyka, wos, wdż]

II. Kompetencje literackie i kulturowe [uczeń/uczennica rozumie dostosowane do wieku teksty kultury, których jest odbiorcą, zna kody, za pomocą których można je interpretować, potrafi o nich rozmawiać, dostrzega w nich emocje i inspiruje się nimi w refleksji o swoich doświadczeniach, odczytuje zawarte $w$ nich myśli, umieszcza je w różnych kontekstach, dzięki nim poznaje innych ludzi, potrafi z empatią mówić o ich doświadczeniu życiowym, emocjach, myślach i światopoglądzie]

Nauczyciel/nauczycielka:

1. Zachęca uczniów do uczestnictwa w kulturze;

2. Inspiruje uczniów do lektury;

Polonistyka. Innowacje

Numer 12, 2020 
3. Towarzyszy uczniowi/uczennicy w interpretacji dzieła;

4. Kieruje pracą analityczną ucznia/uczennicy;

5. Zachęca ucznia/uczennicę do podjęcia samodzielnej pracy twórczej;

6. Inspiruje ucznia/uczennice do podjęcia refleksji nad zagadnieniami, które są poruszane w poznawanych tekstach kultury.

\section{Uczeń/uczennica:}

1. Dokonuje wartościowania dzieła, mówi o własnym przeżyciu lektury:

1.1. Opisuje odczucia, jakie budzi w nim/niej dzieło literackie oraz dzieło z innej dziedziny twórczości; [plastyka, muzyka, informatyka. wdż]

1.2. Omawia specyficzne estetyczne cechy utworu. [plastyka, muzyka, informatyka]

2. Proponuje własną interpretację tekstu i przedstawiajej uzasadnienie:

2.1. Przedstawia problematykę utworu;

2.2. Proponuje interpretację dzieła opartą na uważnej lekturze, wskazuje w utworze fragmenty, które pozwalają uprawomocnić proponowane odczytanie;

2.3. W interpretacji odnosi się do własnego doświadczenia, doświadczenia swojego pokolenia lub społeczeństwa, a zarazem potrafi zracjonalizować związek między przeżyciem a dziełem; [wos, wdż, edukacja dla bezpieczeństwa]

2.4. W interpretacji, jeśli to możliwe, uwzględnia kontekst historyczny powstania utworu, kontekst biograficzny, kontekst filozoficzny, światopoglądowy lub religijny; [historia, etyka, religia]

2.5. W klasycznych utworach literackich i innych tekstach kultury dostrzega treści, które są aktualne dla współczesnego czytelnika; [plastyka, muzyka]

2.6. Potrafi zweryfikować swoją koncepcję interpretacyjną po uważnej analizie dzieła lub po zapoznaniu się z innymi pomysłami interpretacyjni, zarazem potrafi bronić własnej koncepcji, jeśli znajduje dowody na jej uprawomocnienie. [wos, wdż, etyka, religia]

3. Potrafi przeprowadzić analize dzieła, która służy uzasadnieniu odczytania:

3.1. Charakteryzuje perspektywę nadawczą dzieła, określa postać mówiącą w utworze (narrator, podmiot liryczny);

3.2. Przypisuje utwór literacki do rodzaju literackiego (epika, liryka, dramat);

3.3. Przypisuje utwór do epoki, w której powstał; [historia]

3.4. Rozpoznaje gatunki literackie: wiersz (dwudziestowieczny), pieśń, sonet, hymn, ballada, dramat (jako gatunek), komedia, nowela, powieść historyczna, powieść kryminalna (lub opowiadanie), powieść fantastycznonaukowa (lub opowiadanie);

3.5. Wskazuje funkcje użytych $\mathrm{w}$ dziele literackim środków językowych z zakresu słownictwa (języka potocznego, archaizmów, neologizmów, zdrobnień, zgrubień, metafor), składni (powtórzeń, pytań retorycznych, różnego typu zdań i równoważników), fonetyki (rymu, rytmu, wyrazów dźwiękonaśladowczych); [języki obce, język mniejszości etnicznej]

3.6. Omawia funkcje elementów konstrukcyjnych utworu (tytułu, podtytułu, motta, dedykacji, apostrofy, puenty, punktu kulminacyjnego);

3.7. Wskazuje elementy dramatu: akt, scena, tekst główny, tekst poboczny (didaskalia), monolog, dialog;

3.8. Potrafi wskazać cechy charakterystyczne teatru dramatycznego, opery, baletu; 
3.9. Opisuje rolę montażu w filmie dokumentalnym i jego wpływ na wymowę utworu; [informatyka, technika]

3.10. Omawia rolę muzyki w filmie, teatrze, sztukach audiowizualnych. [muzyka]

4. Omawia sposoby przedstawiania świata w tekstach kultury i wpływania na odbiorcę:

4.1. Potrafi odróżnić fikcję od rzeczywistości w filmie i innych formach przekazu audiowizualnego;

4.2. Rozpoznaje perswazję $\mathrm{w}$ filmie fabularnym i dokumentalnym; [wos]

4.3. Omawia sposoby prezentacji rzeczywistości w dziełach plastycznych, wskazuje na różnice między malarstwem, rzeźbą i grafiką a fotografią, dostrzega element dokumentacji i kreacji w różnych formach przekazu plastycznego; [plastyka]

4.4. Omawia sposoby przedstawiania świata i oddawania emocji w dziełach muzycznych. [muzyka]

5. Tworzy wypowiedzi artystyczne, w których wyraża swoje myśli i emocje:

5.1. Pisze krótkie teksty literackie $\mathrm{w}$ innych niż opowiadanie formach gatunkowych (wiersz, scenka dramatyczna, opis);

5.2. Tworzy przekaz $\mathrm{w}$ nieliterackiej formie - zależnie od możliwości i umiejętności w formie muzycznej, plastycznej, filmowej, audiowizualnej. [muzyka, plastyka, informatyka]

6. Wykorzystuje poznane teksty kultury do podjęcia refleksji nad kwestiami tożsamości indywidualnej i narodowej, światopoglądu, uwarunkowań społecznych i historycznych człowieka:

6.1. Przedstawia doświadczenia młodzieży wyrażone za pośrednictwem literatury i filmu; [wos, wdż]

6.2. Na podstawie poznanych dzieł literackich i innych tekstów kultury omawia różne wymiary tożsamości, zwłaszcza narodowej, a także stosunek do inności; [historia, wos, wdż]

6.3. Przedstawia refleksje światopoglądowe, etyczne, historyczne, społeczne wynikające z odbioru dzieł literackich i utworów z innych dziedzin twórczości. [religia, etyka, historia, wos, wdż]

Pod koniec ósmej klasy odbywa się egzamin wieńczący naukę w szkole podstawowej. Egzamin $z$ języka polskiego ma dwa etapy. Pierwszy rozłożony jest $w$ ciągu drugiego semestru - ma charakter ustny. Uczniowie przygotowują prace w dowolnych formach, w tym możliwa jest forma artystyczna. Praca prezentowana jest przed komisją, specjalnym jury lub publicznością. Po prezentacji następuje krótka samodzielna wypowiedź, a następnie krótka rozmowa. Kompetencje komunikacyjne i kulturowe oceniane są według wystandaryzowanego kwestionariusza. Drugi etap (chronologicznie może być wcześniejszy) to test sprawdzający zrozumienie różnego rodzaju tekstów oraz umiejętność stworzenia własnej wypowiedzi pisemnej. Wynik testu wyrażony jest w punktach, ocena egzaminu ustnego ma charakter opisowy. Informacja o wyniku punktowym z testu ma być uzupełniona informacją dotyczącą osiągnięć w poszczególnych obszarach umiejętności. Na koniec ósmej klasy uczniowie otrzymują opisową opinię dotyczącą ich całościowych osiągnięć. Należy w niej podkreślić mocne strony rozwoju uczennicy/ucznia oraz obszary wymagające wzmożonej pracy. Wynik egzaminu po szkole podstawowej ma charakter diagnostyczny (dla ucznia i nauczycieli w szkole średniej) oraz selekcyjny. 
Poziom podstawowy nauczania języka polskiego w liceum i technikum przeznaczony jest dla wszystkich, którzy aspirują do średniego i wyższego wykształcenia, a więc na przykład lekarzy, prawników, inżynierów, księży, mechaników samochodowych z dyplomem technika czy dietetyków z dyplomem technika. Obejmuje niezbędną podczas studiów, w pracy i życiu społecznym sprawność komunikacyjną oraz przygotowanie do pełnego, ale nie specjalistycznego, uczestnictwa w kulturze. Musi obejmować umiejętności i wiedzę niezbędne dla wszystkich osób legitymizujących się maturą. NIE JEST PRZEZNACZONY DLA FILOLOGÓW CZY TEŻ OGÓLNIE HUMANISTÓW. 
Szkoła ponadpodstawowa kończąca się maturą - liceum i technikum, poziom podstawowy (uczeń zdający maturę na poziomie podstawowym wykazuje się następującymi kompetencjami)

I. Kompetencje językowo-komunikacyjne [uczeń/uczennica sprawnie posługuje się językiem w mowie, piśmie oraz innych formach - $w$ tym elektronicznych, rozumie skierowany do niego/niej przekaz, potrafi wyrazić własny przekaz w sposób jasny i zrozumiały dla odbiorcy, wyraża swoje myśli, mówi o emocjach, uczestniczy w komunikacji w grupie i szerszej społeczności]

Nauczyciel/nauczycielka:

1. Kieruje pracą ucznia/uczennicy nad głębokim zrozumieniem poznanej wypowiedzi;

2. Inspiruje ucznia/uczennice do wykorzystywania jego/jej wiedzy o języku w odczytywaniu znaczeń w tekście;

3. Prowadzi ucznia/uczennice $\mathbf{w}$ nauce podstaw retoryki;

4. Wspiera ucznia/uczennice $\mathbf{w}$ opanowywaniu umiejętności samodzielnego tworzenia wypowiedzi w różnych formach, mediach, sytuacjach komunikacyjnych.

\section{Uczeń/uczennica:}

1. Rozumie sens wypowiedzi, której jest odbiorcą, odczytuje znaczenia $\mathrm{z}$ różnych poziomów struktury tekstu:

1.1. Potrafi odczytać sens całości wypowiedzi (napisanej, mówionej, wyrażonej za pośrednictwem obrazu i mediów elektronicznych) oraz jej fragmentów; [język obcy, historia, podstawy przedsiębiorczości]

1.2. Potrafi zrozumieć w wypowiedzi treści wyrażone wprost i treści zawarte w strukturze głębokiej tekstu, informacje jawne i ukryte. [historia]

2. W analizie wypowiedzi potrafi wykorzystać wiedze o języku a także wiedzę o mechanizmach budowania znaczeń słów:

2.1. Wykorzystuje wiedzę o języku do zrozumienia sensu zdań i akapitów; [język obcy, język mniejszości etnicznej, łacina]

2.2. Rozumie pojęcie stylu i wykorzystuje wiedzę o różnych stylach do zrozumienia kontekstu wypowiedzi; [język mniejszości etnicznej]

2.3. Wskazuje cechy charakterystyczne stylu tekstu, rozpoznaje zastosowane w nim środki językowe i wyjaśnia ich funkcje; [język mniejszości etnicznej]

2.4. Rozpoznaje w czytanych tekstach oraz wypowiedziach mówionych stylizację, rozróżnia jej rodzaje (archaizację, dialektyzację, kolokwializację) i objaśnia jej funkcję; [historia, język mniejszości etnicznej]

2.5. Dostrzega w tekście archaizmy i neologizmy, eufemizmy i wulgaryzmy - potrafi określić ich funkcję stylistyczną oraz ekspresyjną, a także wyjaśnić konsekwencje ich użycia w wypowiedzi; [historia, wdż, etyka, religia, język mniejszości etnicznej]

2.6. Rozpoznaje wyrazy wieloznaczne i rozumie ich znaczenie w tekście; [język obcy, język mniejszości etnicznej]

2.7. Rozpoznaje związki frazeologiczne, odczytuje ich znaczenie oraz potrafi wyjaśnić ich funkcję w tekście; [język obcy, język mniejszości etnicznej]

2.8. Dostrzega zróżnicowanie słownictwa - odróżnia słownictwo o ograniczonym zasięgu (regionalne, gwarowe, naukowe) od słownictwa ogólnonarodowego; [język mniejszości etnicznej] 
2.9. Odróżnia słownictwo neutralne od emocjonalnego i wartościującego, oficjalne od swobodnego; [język obcy, język mniejszości etnicznej, wos, wdż]

2.10. Zna zasady poprawności i stosowności językowej i potrafi je zastosować do wypowiedzi odbieranych i formułowanych przez siebie; [język obcy, język mniejszości etnicznej]

2.11. Odróżnia wyrazy rodzime i zapożyczone (obce), rozumie przyczyny dokonywania zapożyczeń językowych, potrafi wskazać lub znaleźć w słownikach słowa rodzime, którymi można zastąpić wyrazy zapożyczone; [język obcy, język mniejszości etnicznej, wos]

2.12. Wyjaśnia znaczenia słów, wykazuje się coraz większym zasobem słownictwa, gdy spotyka słowa nieznane, szuka ich znaczeń w słownikach, dokonuje analizy słowotwórczej, sięga do znajomości języków obcych lub odczytuje ich znaczenie z kontekstu; [język obcy, język mniejszości etnicznej, historia, podstawy przedsiębiorczości]

2.13. Odróżnia pojęcia błędu językowego i zamierzonej innowacji językowej, rozpoznaje i poprawia różne typy błędów językowych.

3. W odczytywaniu sensów wypowiedzi bierze pod uwage gatunki tekstów, media, za pośrednictwem których przekaz dociera do odbiorcy, oraz sposoby konstruowania wypowiedzi:

3.1. Rozpoznaje i wyjaśnia specyfikę tekstów publicystycznych (artykuł, felieton, reportaż), retorycznych (przemówienie, homilia, wykład, prezentacja) i popularnonaukowych; [historia, wos, religia]

3.2. W wypowiedzi medialnej (w każdym typie mediów) odróżnia informację od komentarza; [informatyka, historia, wos]

3.3. W mediach audiowizualnych odczytuje informacje wyrażone za pomocą obrazu i montażu; [informatyka, historia, wos]

3.4. Rozpoznaje typy nadawcy i adresata wypowiedzi. [informatyka, historia, wos]

4. Rozpoznaje retoryczną organizacje tekstu, jego logike i metody wpływania na odbiorcę:

4.1. Wskazuje w wypowiedzi temat, główną myśl, wyrażone wprost lub ukryte założenia, kluczowe pojęcia, tezę lub hipotezę, kluczowe argumenty i argumenty poboczne, tok rozumowania, logikę argumentacji, konkluzję; [matematyka, historia, wos]

4.2. Dokonuje logicznego streszczenia tekstu; [historia, wos, matematyka]

4.3. Rozróżnia w dialogu wypowiedzi właściwe i unikowe; [wos, wdż]]

4.4. Rozpoznaje pytania podchwytliwe oraz sugerujące odpowiedź, potrafi się do nich odnieść;

4.5. Rozpoznaje w wypowiedzi ironię i opisuje jej mechanizm;

4.6. Dostrzega manipulację językową i pozajęzykową (sytuacyjną) w wypowiedzi, opisuje jej mechanizm, potrafi sie jej oprzeć. [historia, wos, wdż, edukacja dla bezpieczeństwa]

\section{Tworzy wypowiedzi we wskazanych gatunkach:}

5.1. Tworzy dłuższą wypowiedź pisaną i mówioną; stawia tezę lub hipotezę, dobiera argumenty, porządkuje je, hierarchizuje, dokonuje ich selekcji pod względem użyteczności w wypowiedzi, dobiera przykłady ilustrujące wywód myślowy, przeprowadza prawidłowe wnioskowanie, podsumowuje; [język obcy, język mniejszości etnicznej, matematyka, historia, wos]

5.2. Pisze rozprawkę zawierającą rozbudowaną spójną i logiczną argumentację; [język mniejszości etnicznej, matematyka, historia, wos, filozofia, etyka] 
5.3. Pisze szkic interpretacyjny, w którym wyrażone opinie są poparte logiczną argumentacją; [matematyka, historia muzyki, historia sztuki, filozofia]

5.4. Pisze recenzję z książki, filmu, spektaklu teatralnego, wystawy, koncertu lub innego wydarzenia kulturalnego, w której przedstawione są najważniejsze informacje, zawarte jest poparte argumentami wartościowanie i uzasadniona interpretacja; [historia muzyki, historia sztuki]

5.5. Pisze i wygłasza referat naukowy z interesującej go dziedziny; [fizyka, biologia, chemia, historia, wos, historia muzyki, historia sztuki, filozofia, etyka, religia]

5.6. Wygłasza przemówienie, wykład lub mowę innego rodzaju, dba o dźwiękową wyrazistość przekazu, w tym o tempo mowy i donośność głosu; [wos, religia]

5.7. Przedstawia rozbudowaną prezentację spełniającą wymagania tego rodzaju wypowiedzi; [informatyka, podstawy przedsiębiorczości]

5.8. Potrafi wypowiadać się przed kamerą i do mikrofonu, dostosowuje swoją wypowiedź do wymogów medium (czas wypowiedzi, modulacja głosu, język ciała); [informatyka, podstawy przedsiębiorczości]

5.9. Tworzy rozbudowane komunikaty multimedialne, dba o zawartość obrazu, infografiki, służący przekazowi montaż; [informatyka]

5.10. Stosuje uczciwe zabiegi perswazyjne, zdaje sobie sprawę z ich wartości i funkcji, wystrzega się nieuczciwych zabiegów erystycznych; [wos, wdż, etyka, religia]

5.11. Zachowuje układ kompozycyjny swojej wypowiedzi, sporządza plan, dobiera odpowiednie słownictwo;

5.12. Tworząc wypowiedzi, dąży do precyzyjnego wysławiania się, świadomie dobiera synonimy i antonimy dla wyrażenia zamierzonych treści; [język obcy, język mniejszości etnicznej, wos, wdż]

5.13. Stosuje różne rodzaje zdań we własnych wypowiedziach; [język obcy, język mniejszości etnicznej]

5.14. Stosuje poprawne formy odmiany rzeczowników, czasowników (w tym imiesłowów), przymiotników, liczebników i zaimków, stosuje poprawne formy wyrazów w związkach składniowych (zgody i rządu);

5.15. Opracowuje redakcyjnie własny tekst - dokonuje uzupełnień, przekształceń, skrótów, poprawek stylistycznych; [język obcy, język mniejszości etnicznej, podstawy przedsiębiorczości]

5.16. Dokonuje edycji tekstu napisanego w formie elektronicznej, dba o jego estetykę, czytelność i zawartość językową; [informatyka, podstawy przedsiębiorczości]

5.17. Potrafi sporządzić opis bibliograficzny książki i artykułu (również opublikowanych w formie elektronicznej), zrobić przypis, przygotować bibliografię do wybranego tematu;

5.18. Posługuje się bogatym słownictwem z zakresu nauki, kultury, filozofii, religii, spraw publicznych. [matematyka, fizyka, biologia, chemia, historia muzyki, historia sztuki, wos, historia, filozofia, etyka, religia]

II. Kompetencje literackie i kulturowe [uczeń/uczennica rozumie teksty kultury, których jest odbiorcą, zna kody, za pomocą których można je interpretować, potrafi o nich rozmawiać, dostrzega w nich emocje i inspiruje sie nimi w refleksji o swoich doświadczeniach, odczytuje zawarte w nich myśli, umieszcza je w różnych kontekstach, dzięki nim poznaje innych ludzi, potrafi z empatią mówić o ich doświadczeniu życiowym, emocjach, myślach i światopoglądzie]

\section{Nauczyciel/nauczycielka:}

1. Zachęca ucznia/uczennice do uczestnictwa w kulturze, przedstawia mu/jej propozycje lektury; 
2. Towarzyszy uczniowi/uczennicy w jego/jej lekturze;

3. Inspiruje ucznia/uczennice do samodzielnej interpretacji tekstu kultury;

4. Kieruje pracą ucznia/uczennicy w wykorzystywaniu wiedzy o literaturze i kulturze w odbiorze tekstów;

5. Moderuje dyskusje uczniów o problemach poruszanych w poznanych tekstach kultury.

\section{Uczeń/uczennica:}

1. Świadomie opisuje swoją sytuację jako odbiorcy tekstu kultury:

1.1. Opisuje własne przeżycia wynikające z doświadczenia odbioru dzieła literackiego oraz utworów z innych dziedzin twórczości (literatura, teatr, film, muzyka, sztuki plastyczne, sztuki audiowizualne); [historia muzyki, historia sztuki, wdż, informatyka]

1.2. Nazywa emocje, które wzbudziło w nim dzieło, poddaje refleksji przyczyny tych emocji; [wdż]

1.3. Określa oczekiwania estetyczne związane z dziełem. [historia muzyki, historia sztuki, filozofia]

2. Wykorzystuje wiedzę z zakresu estetyki i poetyki w analizie tekstu, która ma prowadzić do interpretacji:

2.1. Rozpoznaje konwencję literacką lub artystyczną dzieła; [historia muzyki, historia sztuki]

2.2. Wskazuje wykorzystane $\mathrm{w}$ utworze środki wyrazu artystycznego (np. z zakresu kompozycji, metod rytmizacji, operowania kontrastem) oraz objaśnia ich funkcję; [historia muzyki, historia sztuki, kultura antyczna]

2.3. Rozpoznaje w utworze literackim oksymoron, synekdochę, hiperbolę, elipsę, paralelizm;

2.4. Rozpoznaje gatunki literackie i potrafi opisać ich cechy: epos i epopeję, tragedię, dramat szekspirowski, dramat romantyczny, powieść lub dramat naturalistyczny, powieść psychologiczną, powieść polityczną, dramat groteskowy; [kultura antyczna]

2.5. Dostrzega w dziele kategorie estetyczne tragizm, komizm, groteskę i potrafi wyjaśnić ich funkcję estetyczną oraz filozoficzną. [historia muzyki, historia sztuki, filozofia, kultura antyczna]

3. Samodzielnie interpretuje tekst kultury i uzasadnia swoją interpretację:

3.1. Przedstawia problematykę utworu; [historia muzyki, historia sztuki, filozofia]

3.2. Przedstawia propozycję interpretacji dzieła literackiego oraz utworów z innych dziedzin twórczości; [historia muzyki, historia sztuki, filozofia]

3.3. Przedstawia logiczne uzasadnienie swojej interpretacji, prezentuje argumenty pochodzące z dzieła; [matematyka, historia, historia muzyki, historia sztuki, filozofia]

3.4. Z uwagą analizuje słownictwo utworu literackiego, a także inne elementy językowe, wykorzystuje je w uzasadnieniu interpretacji; [historia, język mniejszości etnicznej, język obcy]

3.5. Rozpoznaje w dziełach sposoby kreowania świata przedstawionego oraz bohaterów;

3.6. Omawia cechy psychologiczne postaci literackich i filmowych, wyjaśnia motywy postępowania i podejmowanych wyborów, dokonuje oceny etycznej, uzasadnia ją; [filozofia, etyka, religia, wdż] 
3.7. W interpretacji odnosi się do swojego własnego doświadczenia, a także doświadczenia i mentalności człowieka współczesnego. [wos, wdż]

4. Wykorzystuje wiedze o literaturze i kulturze w uzasadnieniu swojej interpretacji:

4.1. Omawia sposoby budowania fabuły, prowadzenia narracji, przedstawiania sytuacji lirycznej;

4.2. Potrafi wyjaśnić różnice językowe $\mathrm{w}$ tekstach literackich $\mathrm{z}$ dawnych epok w stosunku do polszczyzny współczesnej, wie, gdzie szukać objaśnień niezrozumiałych słów, znaczenia słów z minionych epok uwzględnia w propozycji interpretacyjnej; [historia]

4.3. Dostrzega w odbieranych dziełach cechy charakterystyczne epoki, w której powstało; [historia muzyki, historia sztuki, historia, kultura antyczna]

4.4. Potrafi przedstawić najważniejsze cechy estetyki i światopoglądu epok w dziejach kultury: antyku, średniowiecza, odrodzenia, baroku, oświecenia, romantyzmu, pozytywizmu, Młodej Polski, modernizmu dwudziestowiecznego (z podziałem na dwudziestolecie międzywojenne i kulturę powojenną), postmodernizmu; [historia muzyki, historia sztuki, filozofia, historia, kultura antyczna]

4.5. Omawia najważniejsze zagadnienia światopoglądowe, egzystencjalne, filozoficzne, polityczne, religijne, które dostrzega w interpretowanym utworze; [historia, wos, filozofia, kultura antyczna, etyka, religia, wdż]

4.6. Wykorzystuje klasyczne dzieła literackie i inne teksty kultury do refleksji nad ogólnoludzkimi problemami egzystencjalnymi, etycznymi i światopoglądowymi; [historia muzyki, historia sztuki, filozofia, kultura antyczna, etyka, religia]

4.7. Wykorzystuje w interpretacji konteksty polityczne, filozoficzne, światopoglądowe czy religijne, uzasadnia ich wykorzystanie; [wos, historia muzyki, historia sztuki, filozofia, kultura antyczna, historia, etyka, religia]

4.8. W interpretacji uwzględnia kontekst historyczny powstania utworu (z zakresu historii literatury i kultury oraz - jeśli to potrzebne - historii politycznej); [historia muzyki, historia sztuki, filozofia, kultura antyczna, historia]

4.9. Potrafi w interpretacji wykorzystać wiedzę o biografii autora (jeśli to potrzebne) i innych kontekstach pomagających zrozumieć genezę utworu; [historia muzyki, historia sztuki, filozofia, kultura antyczna, historia]

4.10. Odczytuje w dziełach treści alegoryczne i symboliczne, potrafi wyjaśnić znaczenie alegorii oraz uzasadnić odczytanie symbolu. [historia muzyki, historia sztuki, filozofia, kultura antyczna, historia]

5. Stosuje interpretację porównawczą tekstów kultury z różnych dziedzin twórczości:

5.1. Przedstawia interpretację porównawczą utworów, wskazuje cechy wspólne i różnice; [historia muzyki, historia sztuki, filozofia, kultura antyczna]

5.2. Porównuje dzieła z różnych dziedzin twórczości - np. utwory literackie z filmami i spektaklami teatralnymi, dzieła malarskie z utworami muzycznymi, itd., omawia specyfikę poszczególnych dziedzin twórczości i wynikające $\mathrm{z}$ tego konsekwencje dotyczące estetyki oraz wymowy; [historia muzyki, historia sztuki, filozofia]

5.3. Porównuje funkcjonowanie tych samych motywów w różnych dziełach z tej samej epoki i innych epok oraz dziełach z poszczególnych dziedzin twórczości. [historia muzyki, historia sztuki, kultura antyczna] 
6. W interpretacji podejmuje ważne problemy filozoficzne, światopoglądowe, egzystencjalne, rozważa kwestię tożsamości indywidualnej, społecznej i narodowej:

6.1. Poddaje analizie obecne w dziełach wartości uniwersalne i narodowe, uzasadnia ich odczytanie, ustosunkowuje się do nich, podaje argumenty przemawiające za swoją opinią; [historia, wos, historia muzyki, historia sztuki, filozofia, etyka, religia]

6.2. W klasycznych dziełach literackich i innych tekstach kultury wskazuje elementy kodu kultury polskiej, europejskiej i ogólnoludzkiej; [historia, wos, historia muzyki, historia sztuki, kultura antyczna, filozofia, etyka, religia]

6.3. Poddaje refleksji własną tożsamość kulturową, potrafi przedstawić i omówić elementy innych tożsamości; [wdż, wos, filozofia, historia, etyka, religia]

6.4. Dostrzega w literaturze i sztuce konflikty wartości, potrafi wskazać źródła tych konfliktów, podejmuje refleksję nad możliwością bądź niemożliwością ich rozwiązania. [wdż, wos, filozofia, kultura antyczna, etyka, religia]

Egzamin maturalny $z$ języka polskiego na poziomie podstawowym ma dwa etapy. Pierwszy, rozłożony jest w ciągu drugiego semestru, ma charakter ustny. Uczniowie przygotowują samodzielne wypowiedzi w wybranych formach poznanych w szkole (prezentacja, mowa, referat itd.). Wypowiedź powinna dotyczyć zagadnień interesujących dla uczniów, być może związanych z planami naukowymi lub zawodowymi, ale $\mathrm{z}$ odniesieniem do kultury. Po zaprezentowanej wypowiedzi następuje krótka rozmowa $z$ jury. Kompetencje komunikacyjne i kulturowe oceniane są według wystandaryzowanego kwestionariusza. Drugi etap (chronologicznie może być wcześniejszy) to egzamin sprawdzający umiejętności interpretacyjne różnego typu tekstów, wiedzę $z$ zakresu objętego przez podstawe programową oraz umiejętność napisania odnoszącego się do kultury tekstu, w którym zostaje rozważony istotny problem. Wynik egzaminu pisemnego wyrażony jest $w$ punktach, ocena egzaminu ustnego ma charakter opisowy. Informacja o wyniku punktowym z testu ma być uzupełniona informacją dotyczącą osiągnięć w poszczególnych obszarach umiejętności. Na świadectwie maturalnym uczniowie otrzymują opisową opinię dotyczącą ich całościowych osiągnięć. Należy w niej podkreślić mocne strony rozwoju uczennicy/ucznia oraz obszary wymagające wzmożonej pracy. Wynik egzaminu po szkole ponadpodstawowej ma charakter diagnostyczny jako załącznik do przyszłego CV oraz selekcyjny w rekrutacji na wyższe studia.

Poziom rozszerzony nauczania języka polskiego w liceum przeznaczony jest dla kandydatów na filologie, zwłaszcza na filologię polską, ewentualnie na inne studia humanistyczne. Dlatego podstawa programowa do nauczania na poziomie rozszerzonym musi służyć przygotowywaniu do tego typu studiów, a matura zdana na poziomie rozszerzonym powinna dawać wstęp właśnie na te studia. Stąd konieczność bardzo wysoko postawionych wymagań. 
Szkoła ponadpodstawowa kończąca się maturą - liceum i technikum, poziom rozszerzony (uczeń zdający maturę na poziomie rozszerzonym wykazuje się następującymi kompetencjami)

I. Kompetencje językowo-komunikacyjne [uczeń/uczennica bardzo sprawnie posługuje się językiem w mowie, piśmie oraz innych formach - w tym elektronicznych, rozumie skierowany do niego/niej przekaz, potrafi wyrazić własny przekaz w sposób jasny i zrozumiały dla odbiorcy, wyraża swoje myśli, mówi o emocjach, uczestniczy w komunikacji w grupie i szerszej społeczności]

\section{Nauczyciel/nauczycielka:}

1. Inspiruje ucznia/uczennice do poznawania wiedzy o języku, retoryce, komunikacji, mediach;

2. Towarzyszy uczniowi/uczennicy w samokształceniu;

3. Kieruje pracą ucznia/uczennicy w naukowej analizie wypowiedzi;

4. Zachęca ucznia/uczennice do tworzenia własnych wypowiedzi.

\section{Uczeń/uczennica:}

1. Wyjaśnia zasadę semiotycznego funkcjonowania języka:

1.1. Zna i wyjaśnia pojęcie znaku i systemu znaków; [język obcy, język mniejszości etnicznej]

1.2. Rozróżnia znaki werbalne i niewerbalne;

1.3. Potrafi opisać język jako system znaków; [język obcy, język mniejszości etnicznej]

1.4. Omawia symboliczną nature języka;

1.5. Objaśnia różne funkcje znaków i sposoby ich interpretacji;

1.6. Odróżnia znaczenie realne i etymologiczne wyrazu.

2. Omawia mechanizm komunikacji i kognitywnego aspektu języka:

2.1. Zna pojęcie aktu komunikacji językowej i wskazuje jego składowe (nadawca, odbiorca, kod, kontakt, komunikat, kontekst);

2.2. Omawia funkcje języka - poznawczą, komunikacyjną oraz społeczną;

2.3. Rozpoznaje i nazywa funkcje tekstu - informacyjną, poetycką, ekspresywną, impresywną (w tym perswazyjną);

2.4. Omawia relację, która zachodzi między językiem a obrazem świata. [język obcy, język mniejszości etnicznej, język łaciński]

3. Potrafi omówić specyfike języka polskiego na tle innych języków oraz przedstawić różnorodność odmian języka polskiego:

3.1. Przedstawia cechy języka polskiego, które świadczą o jego przynależności do języków słowiańskich; [język obcy, język mniejszości etnicznej]

3.2. Sytuuje język polski na tle innych języków używanych w Europie; [język obcy, język mniejszości etnicznej, język łaciński]

3.3. Wskazuje w czytanych tekstach i analizuje przykłady odmian terytorialnych, środowiskowych i zawodowych polszczyzny.

4. Potrafi wykorzystać wiedze językoznawczą do opisu specyfiki języka polskiego:

4.1. Rozróżnia pojęcia głoski i fonemu, opisuje system fonologiczny języka polskiego, porównuje go z systemami innych języków;

4.2. Wyjaśnia pojęcie morfemu, przedstawia system morfologiczny polszczyzny; 
4.3. Omawia fleksję języka polskiego, zna zasady odmiany przez przypadki, rodzaje, osoby, czasy, liczby, strony, porównuje system fleksyjny polszczyzny z systemami innych języków;

4.4. Wyjaśnia pojęcia tematu słowotwórczego, podstawy słowotwórczej i formantu, przeprowadza analizy słowotwórcze wyrazów, omawia konsekwencje operacji słowotwórczych dla semantyki, porównuje system słowotwórczy polszczyzny z innymi językami;

4.5. Rozpoznaje w zdaniach i w równoważnikach zdań różne rodzaje podmiotów, orzeczeń, dopełnień, okoliczników oraz przydawkę - rozumie ich funkcję;

4.6. Rozróżnia rodzaje zdań złożonych podrzędnie i współrzędnie, imiesłowowe równoważniki zdań, zdania bezpodmiotowe oraz rozumie ich funkcje w wypowiedzi;

4.7. Omawia system składniowy polszczyzny, porównuje go z systemami innych języków;

4.8. Potrafi omówić relację między strukturą fonologiczną i semantyczną języka; [język obcy, język mniejszości etnicznej]

4.9. Opisuje style polszczyzny (potoczny, artystyczny, naukowy, urzędowy, publicystyczny), wskazuje ich cechy oraz omawia funkcje w systemie.

5. Opisuje mechanizmy tworzenia tekstu i oddziaływania na odbiorcę:

5.1. Rozpoznaje i opisuje retoryczną organizację wypowiedzi, celowość zastosowanych rozwiązań;

5.2. Potrafi dostrzec i poddać analizie mechanizmy języka perswazji, manipulacji, nowomowy; [wos, historia]

5.3. Omawia zasady i problemy przekładu literackiego. [język obcy, język mniejszości etnicznej, język łaciński]

6. Wykorzystuje wiedze o mediach i niewerbalnych formach komunikacji do analizy tekstów:

6.1. Dostrzega i omawia zmiany we współczesnej komunikacji językowej, bierze pod uwagę rolę mediów elektronicznych; [informatyka]

6.2. Porównuje tekst linearny z hipertekstem; [informatyka]

6.3. Potrafi zestawić i zinterpretować teksty wyrażone w różnych systemach znakowych (np. językowym i graficznym, językowym i audiowizualnym itd.);

6.4. Omawia rolę czynników niewerbalnych w przekazie.

7. Wykorzystuje wiedze o języku, zasadach retoryki i edytorstwa do tworzenia własnych i redagowania cudzych wypowiedzi:

7.1. Potrafi przedstawić najważniejsze tezy książek i artykułów językoznawczych; [język obcy, język mniejszości etnicznej, język łaciński]

7.2. Tworzy wypowiedzi - pisemne i ustne - perswazyjne ze świadomością ich aspektu performatywnego;

7.3. Wykorzystuje media elektroniczne do tworzenia przekazu łączącego różne systemy komunikacyjne; [informatyka]

7.4. Przeprowadza redakcję oraz sporządza korektę cudzego tekstu.

II. Kompetencje literackie i kulturowe [uczeń/uczennica rozumie teksty kultury, których jest odbiorcą, zna kody, za pomocą których można je interpretować, potrafi o nich rozmawiać, dostrzega w nich emocje i inspiruje się nimi w refleksji o swoich doświadczeniach, odczytuje zawarte w nich myśli, umieszcza je w różnych kontekstach, dzięki nim poznaje innych ludzi, potrafi z empatią mówić o ich doświadczeniu życiowym, emocjach, myślach i światopoglądzie] 


\section{Nauczyciel/nauczycielka:}

1. Inspiruje ucznia/uczennice do poznawania wiedzy o literaturze i kulturze;

2. Zachęca ucznia/uczennicę do uczestnictwa w kulturze współczesnej;

3. Towarzyszy uczniowi/uczennicy w samokształceniu;

4. Kieruje pracą ucznia/uczennicy w wykorzystaniu wiedzy o literaturze i kulturze w procesie analizy i interpretacji dzieła;

5. Zachęca do tworzenia przez ucznia/uczennice samodzielnej wypowiedzi, koryguje ewentualne błędy lub potknięcia.

\section{Uczeń/uczennica:}

1. Potrafi wykorzystać współczesną wiedzę o literaturze w analizie i interpretacji dzieła:

1.1. Poznaje różne współczesne metodologie badań literackich (strukturalizm, poststrukturalizm, dekonstrukcjonizm, pragmatyzm, badania kulturowe, feminizm) i stosuje je w interpretacji dzieła;

1.2. Czyta książki i artykuły z zakresu wiedzy o literaturze i kulturze oraz potrafi je wykorzystać jako kontekst w interpretacji dzieła; [historia muzyki, historia sztuki, filozofia, kultura antyczna]

1.3. Twórczo wykorzystuje wypowiedzi krytycznoliterackie (recenzje, szkice, eseje) w pracy z tekstem; [historia muzyki, historia sztuki, filozofia]

1.4. Omawia związki między różnymi elementami struktury utworu a także różnymi jego aspektami (estetycznym, etycznym, poznawczym); [historia muzyki, historia sztuki, filozofia]

1.5. Rozpoznaje w dziełach znaki tradycji, alegorie, aluzje i cytaty kulturowe; [historia muzyki, historia sztuki, filozofia, kultura antyczna]

1.6. Omawia cechy epok w dziejach kultury, ich założenia filozoficzne, główne style, prądy i kierunki; [historia muzyki, historia sztuki, filozofia, kultura antyczna]

1.7. Potrafi przedstawić poglądy najważniejszych filozofów i myślicieli religijnych; [historia muzyki, historia sztuki, filozofia, etyka, religia, kultura antyczna]

1.8. Potrafi wyjaśnić pojęcie kodu kulturowego, podejmuje pogłębioną refleksję nad polskim, europejskim i ogólnoludzkim kodem kulturowym, wskazuje elementy kodu kulturowego w klasycznych oraz współczesnych tekstach kultury; [historia muzyki, historia sztuki, filozofia, etyka, religia, kultura antyczna]

1.9. Dostrzega w utworach parodię, parafrazę i trawestację, wskazuje ich wzorce kulturowe;

1.10. Dostrzega i omawia przemiany konwencji literackich i artystycznych w ciągu dziejów, a także ich żywotność oraz praktykę łączenia i wzajemnego podważania w kulturze współczesnej;

1.11. Rozpoznaje gatunki literackie, omawia ich cechy oraz rozwój;

1.12. Potrafi omówić cechy wersyfikacji utworu (zna systemy sylabiczny, sylabotoniczny, toniczny i wolny);

1.13. Omawia zasady kompozycji utworu, wyjaśnia jej rolę w budowie znaczeń;

1.14. Opisuje i wartościuje estetyczne walory utworu, uzasadnia swoje sądy, odwołuje się do wiedzy z zakresu poetyki oraz historii literatury. [kultura antyczna, historia muzyki, historia sztuki] 
2. Samodzielnie interpretuje dzieła literackie i inne teksty kultury z różnych epok, szczególnie jednak utwory powstałe w nieodległej przeszłości:

2.1. Porównuje dzieła z różnych epok, różnych kręgów kulturowych i różnych dziedzin twórczości; [historia muzyki, historia sztuki, filozofia]

2.2. Interpretuje eseje i felietony, wykorzystuje wiedzę o tych gatunkach, a także wiedzę o kontekście historycznym, społecznym, filozoficznym; [historia muzyki, historia sztuki, filozofia, historia, wos, kultura antyczna]

2.3. Interpretuje utwory z literatury i kultury najnowszej, proponuje własne odczytanie, konfrontuje je z odczytaniem kolegów/koleżanek oraz recenzentów;

2.4. Przeprowadza interpretację spektakli teatralnych, w których uwzględnia różne aspekty spektaklu (reżyseria, gra aktorska, scenografia, muzyka i inne) i odczytuje sens, który dzięki nim zyskuje dzieło;

2.5. W interpretacji filmu i innych form sztuki audiowizualnej analizuje warstwę obrazową, montaż, grę aktorską i inne elementy, a także całość dzieła jako efekt koncepcji reżyserskiej;

2.6. Dokonuje odczytania dzieł plastycznych jako tekstów wyrażonych w kodzie ikonicznym, bierze pod uwagę rozwiązania formalne, odniesienia do tradycji, gry z symbolami; [historia sztuki, kultura antyczna]

2.7. Potrafi posłużyć się specjalistycznym słownictwem do opisania i zinterpretowania dzieła muzycznego, porównania jego estetyki z twórczością w innych dziedzinach tej samej epoki; [historia muzyki]

2.8. Dokonuje pogłębionej interpretacji dzieł z uwzględnieniem wiedzy filozoficznej, kulturowej, historycznej, religijnej. [filozofia, historia muzyki, historia sztuki, historia, religia, kultura antyczna]

3. Potrafi w dojrzały, pogłębiony sposób zaprezentować swoje poglądy i przemyślenia na temat kultury:

3.1. Podejmuje refleksję nad kulturą współczesną, tradycją, dziedzictwem ogólnoludzkim, europejskim i polskim, wykorzystuje wybrane dzieła literackie i artystyczne; [filozofia, historia muzyki, historia sztuki, historia, religia]

3.2. Omawia specyfikę kultury polskiej w kontekście europejskim i globalnym; [filozofia, historia muzyki, historia sztuki, historia]

3.3. Pisze eseje, referaty i recenzje;

3.4. Wygłasza wykład, przedstawia prezentacje na wybrany temat z zakresu humanistyki. [filozofia, historia muzyki, historia sztuki, historia, religia, etyka]

Egzamin maturalny z języka polskiego na poziomie rozszerzonym ma dwa etapy. Pierwszy rozłożony jest $w$ ciągu drugiego semestru, ma charakter ustny (egzamin ustny na poziomie rozszerzonym zwalnia z egzaminu ustnego na poziomie podstawowym) . Uczniowie przygotowują samodzielne wypowiedzi $w$ wybranych formach poznanych $w$ szkole (prezentacja, mowa, wykład, referat itd., możliwa jest debata przeprowadzona przez kilka osób). Wypowiedź powinna dotyczyć zagadnień z zakresu wiedzy objętego zapisami podstawy programowej na poziomie podstawowym i rozszerzonym. Po zaprezentowanej wypowiedzi następuje krótka rozmowa $z$ jury. Kompetencje komunikacyjne i kulturowe oceniane są według wystandaryzowanego kwestionariusza. Drugi etap (chronologicznie może być wcześniejszy) to egzamin pisemny polegający na stworzeniu eseju na tematy dotyczące ważnych zagadnień filozoficznych, społecznych, kulturowych (artystycznych, komunikacyjnych, lingwistycznych). Ocena egzaminu pisemnego i ustnego na poziomie rozszerzonym ma charakter opisowy. Należy w niej podkreślić mocne strony osiągnięć 
absolwentki/absolwenta oraz obszary, w których nie osiągnęła/nie osiągnął zadowalających rezultatów. Wynik egzaminu maturalnego ma charakter diagnostyczny jako załącznik do przyszłego CV oraz selekcyjny w rekrutacji na wyższe studia humanistyczne.

Lekcje języka polskiego w szkołach branżowych I stopnia powinny służyć rozwinięciu niezbędnych kompetencji językowo-komunikacyjnych i literacko-kulturowych przyszłych pracowników niższego szczebla, fachowców w swoich dziedzinach. 
I. Kompetencje językowo-komunikacyjne [uczeń/uczennica sprawnie posługuje się językiem w mowie, piśmie oraz innych formach - w tym elektronicznych, rozumie skierowany do niego/niej przekaz, potrafi wyrazić własny przekaz w sposób jasny i zrozumiały dla odbiorcy, wyraża swoje myśli, mówi o emocjach, uczestniczy w komunikacji w grupie i szerszej społeczności]

Nauczyciel/nauczycielka:

1. Inspiruje ucznia/uczennice do wnikliwej analizy odebranej wypowiedzi;

2. Zachęca ucznia/uczennice do przyglądania się mechanizmom wpływania na odbiorce przekazu;

3. Zachęca ucznia/uczennicę do uważnego przyglądania się medium, za pomocą którego została przekazana wypowiedź;

4. Inspiruje ucznia/uczennice do wzbogacania słownictwa;

5. Kieruje pracą ucznia/uczennicy nad tworzeniem wypowiedzi.

\section{Uczeń/uczennica:}

1. Rozumie przekaz zawarty $w$ wypowiedzi:

1.1. Potrafi odczytać sens całości wypowiedzi (napisanej, mówionej, wyrażonej za pośrednictwem obrazu i mediów elektronicznych) oraz jej fragmentów; [język obcy, język mniejszości etnicznej, historia]

1.2. Rozumie sens całości instrukcji, przepisu, polecenia, rozkazu, zawiadomienia, listu, e-maila - odczytuje znaczenie wszystkich słów, potrafi odtworzyć logikę przekazu; [język obcy, język mniejszości etnicznej, edukacja dla bezpieczeństwa, podstawy przedsiębiorczości]

1.3. Odczytuje sens wypowiedzi rozmówcy, pyta o słowa i fragmenty wypowiedzi, których nie rozumie, prosi o doprecyzowanie wypowiedzi; [język obcy, język mniejszości etnicznej, wdż, wos]

1.4. Właściwie odczytuje sens przekazu niewerbalnego w wypowiedzi rozmówcy (język ciała, gest, mimika, ton głosu), potrafi zweryfikować nietrafne odczytanie; [wdż]

1.5. Rozróżnia w dialogu wypowiedzi właściwe i unikowe; [wdż]

1.6. Rozpoznaje pytania podchwytliwe oraz sugerujące odpowiedź, potrafi się do nich odnieść. [wdż]

2. Potrafi dostrzec mechanizmy językowe wpływające na zachowanie odbiorcy:

2.1. Rozpoznaje manipulację językową i pozajęzykową (sytuacyjną) w wypowiedzi, opisuje jej mechanizm, potrafi się jej oprzeć; [historia, wos, edukacja dla bezpieczeństwa, etyka, religia, wdż]

2.2. Zna konsekwencje stosowania agresji słownej, użycia wulgaryzmów, posługiwania się mową nienawiści. [historia, wos, edukacja dla bezpieczeństwa, wdż, etyka, religia]

3. Wzbogaca słownictwo i wykorzystuje zrozumienie słów w formulowaniu przekazu i zrozumieniu wypowiedzi, dba o poprawność językową w celu osiągnięcia pełnej komunikatywności:

3.1. Wyjaśnia znaczenia słów, wykazuje się coraz większym zasobem słownictwa, gdy spotyka słowa nieznane, szuka ich znaczeń w słownikach, dokonuje analizy słowotwórczej, sięga do znajomości języków obcych 
lub odczytuje ich znaczenie z kontekstu; [język obcy, język mniejszości etnicznej]

3.2. Rozpoznaje wyrazy wieloznaczne i rozumie ich znaczenie w wypowiedzi; [język obcy, język mniejszości etnicznej]

3.3. Rozpoznaje związki frazeologiczne, odczytuje ich znaczenie oraz potrafi wyjaśnić ich funkcję w tekście; [język obcy, język mniejszości etnicznej]

3.4. Dostrzega zróżnicowanie słownictwa - odróżnia słownictwo o ograniczonym zasięgu (regionalne, gwarowe, naukowe) od słownictwa ogólnonarodowego, potrafi zrozumieć wypowiedź wyrażoną w odmianie języka innej niż używana przez niego na co dzień; [język mniejszości etnicznej]

3.5. Zna zasady poprawności i stosowności językowej i potrafi je zastosować do formułowanych przez siebie wypowiedzi. [język obcy, język mniejszości etnicznej]

4. Dostrzega specyfike wypowiedzi w zależności od medium i gatunku, analizuje strukturę tekstu w celu dobrego zrozumienia go:

4.1. Rozpoznaje i wyjaśnia specyfikę tekstów publicystycznych (artykuł, felieton, reportaż), retorycznych (przemówienie, homilia, wykład, prezentacja) i popularnonaukowych; [wos, religia]

4.2. W wypowiedzi medialnej (w każdym typie mediów) odróżnia informację od komentarza; [informatyka, historia, wos]

4.3. Wskazuje w wypowiedzi temat, główną myśl, wyrażone wprost lub ukryte założenia, kluczowe pojęcia, tezę lub hipotezę, kluczowe argumenty i argumenty poboczne, tok rozumowania, logikę argumentacji, konkluzję. [matematyka, historia, wos]

5. Formułuje jasny i zrozumiały dla odbiorcy przekaz:

5.4. Jasno wyjaśnia słuchaczowi zagadnienia związane $\mathrm{z}$ jego zawodem; [podstawy przedsiębiorczości, kształcenie zawodowe]

5.5. Przejrzyście formułuje instrukcje i polecenia, w formie ustnej i pisemnej; [podstawy przedsiębiorczości, kształcenie zawodowe]

5.6. Potrafi klarownie wyjaśnić swoje racje w różnych sytuacjach zawodowych, oficjalnych, rodzinnych i towarzyskich; [podstawy przedsiębiorczości, kształcenie zawodowe, wos, wdż]

5.7. Stosuje uczciwe zabiegi perswazyjne, zdaje sobie sprawę z ich wartości i funkcji, wystrzega się nieuczciwych zabiegów erystycznych; [podstawy przedsiębiorczości, wos, wdż]

5.8. Pisze rozprawkę zawierającą rozbudowaną spójną i logiczną argumentację; [matematyka, historia, wos]

5.9. Zachowuje układ kompozycyjny swojej wypowiedzi, sporządza plan, dobiera odpowiednie słownictwo;

5.10. Przedstawia rozbudowaną prezentację spełniającą wymagania tego rodzaju wypowiedzi. [informatyka]

II. Kompetencje literackie i kulturowe [uczeń/uczennica rozumie teksty kultury, których jest odbiorcą, zna kody, za pomocą których można je interpretować, potrafi o nich rozmawiać, dostrzega w nich emocje i inspiruje sie nimi w refleksji o swoich doświadczeniach, odczytuje zawarte w nich myśli, umieszcza je w różnych kontekstach, dzięki nim poznaje innych ludzi, potrafi z empatią mówić o ich doświadczeniu życiowym, emocjach, myślach i światopoglądzie]

Nauczyciel/nauczycielka:

1. Inspiruje ucznia/uczennicę do uczestnictwa w kulturze;

2. Zachęca do lektury; 
3. Towarzyszy uczniowi/uczennicy w akcie odbioru dzieła;

4. Zachęca ucznia/uczennice do samodzielnej interpretacji tekstu kultury, nadzoruje proces uzasadniania koncepcji interpretacyjnej;

5. Inspiruje do mówienia o specyfice kultury polskiej, problemach światopoglądowych czy psychologicznych.

\section{Uczeń/uczennica:}

1. Świadomie dokonuje aktu odbioru tekstu kultury, potrafi omówić swoją sytuację odbioru:

1.1. Opisuje własne przeżycia wynikające z doświadczenia odbioru dzieła literackiego oraz utworów z innych dziedzin twórczości (literatura, teatr, film, muzyka, sztuki plastyczne, sztuki audiowizualne); [historia, informatyka, wdż]

1.2. Potrafi zaprezentować utwory z różnych dziedzin twórczości, które mu się podobają, poruszają go, inspirują;

1.3. Nazywa emocje, które wzbudziło w nim poznane dzieło, poddaje refleksji przyczyny tych emocji. [wdż]

2. Interpretuje dzieło literackie lub inny tekst kultury, prezentuje argumenty przemawiające za propozycją interpretacyjną:

2.1. Rozpoznaje konwencję literacką lub artystyczną dzieła; [historia]

2.2. Przedstawia problematykę utworu;

2.3. Przedstawia propozycję interpretacji dzieła literackiego oraz utworów z innych dziedzin twórczości; [historia]

2.4. Przedstawia logiczne uzasadnienie swojej interpretacji, prezentuje argumenty pochodzące z dzieła; [matematyka, historia]

2.5. Z uwagą analizuje słownictwo utworu literackiego, a także inne elementy językowe, wykorzystuje je w uzasadnieniu interpretacji;

2.6. W interpretacji odnosi się do swojego własnego doświadczenia, a także doświadczenia i mentalności człowieka współczesnego; [wos,wdż]

2.7. Omawia najważniejsze zagadnienia światopoglądowe, egzystencjalne, filozoficzne, polityczne, religijne, które dostrzega w interpretowanym utworze. [historia, wos, etyka, religia]

3. Wypowiada się o specyfice kultury polskiej, tożsamości narodowej wyrażonej w literaturze i kulturze:

3.1. Potrafi omówić wybrane szczególnie ważne klasyczne teksty kultury polskiej;

3.2. Poddaje refleksji specyfikę kultury polskiej w kontekście innych kultur.

4. Potrafi omówić problemy światopoglądowe, psychologiczne i moralne dostrzeżone $w$ poznanych tekstach kultury:

4.1. Rozpoznaje $\mathrm{w}$ dziełach sposoby kreowania świata przedstawionego oraz bohaterów;

4.2. Omawia cechy psychologiczne postaci literackich i filmowych, wyjaśnia motywy postępowania i podejmowanych wyborów, dokonuje oceny etycznej, uzasadnia ją. [etyka, religia, wdż]

Egzamin zawodowy obejmuje również kompetencje komunikacyjne. Część pisemna zawiera test z rozumienia przeczytanego tekstu użytkowego, publicystycznego lub literackiego oraz napisanie związanego z zawodem tekstu użytkowego (instrukcja, przepis, opis narzędzia z uwzględnieniem jego działania itd.). W trakcie ustnego egzaminu zawodowego ocenie podlegają umiejętności komunikacyjne. Ocena $z$ egzaminu pisemnego wyrażona jest $w$ punktach, ale dołączony jest opis, jak zostały opanowane poszczególne umiejętności. 
Ocena z egzaminu ustnego (części polonistycznej egzaminu zawodowego) ma charakter opisowy. Podkreśla sie mocne strony osiągnięć absolwentki/absolwenta oraz obszary, w których nie osiągnęła/nie osiągnął zadowalających rezultatów. Wynik egzaminu zawodowego ma charakter diagnostyczny jako załącznik do przyszłego CV oraz selekcyjny w rekrutacji do szkoły branżowej drugiego stopnia.

Szkoła branżowa II stopnia nie tylko służy rozwijaniu kwalifikacji zawodowych, ale również ma przygotować do matury - tak więc konieczne jest takie uzupełnienie kompetencji, które umożliwi absolwentom osiągnięcie poziomu umiejętności i wiedzy na poziomie zbliżonym do poziomu absolwentów techników i liceów. 


\section{Szkoła ponadpodstawowa kończąca się maturą - szkołą branżowa drugiego stopnia}

I. Kompetencje językowo-komunikacyjne [uczeń/uczennica sprawnie posługuje się językiem w mowie, piśmie oraz innych formach - w tym elektronicznych, rozumie skierowany do niego/niej przekaz, potrafi wyrazić własny przekaz w sposób jasny i zrozumiały dla odbiorcy, wyraża swoje myśli, mówi o emocjach, uczestniczy w komunikacji w grupie i szerszej społeczności]

Nauczyciel/nauczycielka:

1. Wspiera ucznia/uczennice $\mathbf{w}$ akcie rozumienia wypowiedzi;

2. Zachęca ucznia/uczennice do pogłębionej analizy struktury tekstu i sytuacji komunikacyjnej;

3. Kieruje pracą ucznia/uczennicy w tworzeniu własnych wypowiedzi.

\section{Uczeń/uczennica:}

1. Rozumie sens wypowiedzi, której jest odbiorcą, odczytuje znaczenia $\mathrm{z}$ różnych poziomów struktury tekstu, wykorzystuje wiedze o języku do analizy znaczeń zawartych $w$ wypowiedzi:

1.1. Potrafi zrozumieć w wypowiedzi treści wyrażone wprost i treści zawarte w strukturze głębokiej tekstu, informacje jawne i ukryte; [historia, wos, wdż]

1.2. Wykorzystuje wiedzę o języku do zrozumienia sensu zdań i akapitów; [język obcy]

1.3. Rozumie pojęcie stylu i wykorzystuje wiedzę o różnych stylach do zrozumienia kontekstu wypowiedzi;

1.4. Wskazuje cechy charakterystyczne stylu tekstu, rozpoznaje zastosowane w nim środki językowe i wyjaśnia ich funkcje;

1.5. Rozpoznaje w czytanych tekstach oraz wypowiedziach mówionych stylizację, rozróżnia jej rodzaje (archaizację, dialektyzację, kolokwializację) i objaśnia jej funkcję; [historia]

1.6. Dostrzega w tekście archaizmy i neologizmy, eufemizmy i wulgaryzmy - potrafi określić ich funkcję stylistyczną oraz ekspresyjną, a także wyjaśnić konsekwencje ich użycia w wypowiedzi; [historia]

1.7. Odróżnia słownictwo neutralne od emocjonalnego i wartościującego, oficjalne od swobodnego; [język obcy, wos, wdż]

1.8. Odróżnia wyrazy rodzime i zapożyczone (obce), rozumie przyczyny dokonywania zapożyczeń językowych, potrafi wskazać lub znaleźć w słownikach słowa rodzime, którymi można zastąpić wyrazy zapożyczone; [język obcy]

1.9. Odróżnia pojęcia błędu językowego i zamierzonej innowacji językowej, rozpoznaje i poprawia różne typy błędów językowych.

2. W rozumieniu przekazu bierze pod uwage sytuacje komunikacyjną, medium oraz strukture wypowiedzi, logikę i rozwiązania retoryczne, które zostały w niej wykorzystane:

2.1. W mediach audiowizualnych odczytuje informacje wyrażone za pomocą obrazu i montażu; [informatyka., wos]

2.2. Rozpoznaje typy nadawcy i adresata wypowiedzi; [informatyka]

2.3. Wskazuje w wypowiedzi temat, główną myśl, wyrażone wprost lub ukryte założenia, kluczowe pojęcia, tezę lub hipotezę, kluczowe argumenty i argumenty poboczne, tok rozumowania, logikę argumentacji, konkluzję; [matematyka, historia]

2.4. Dokonuje logicznego streszczenia tekstu;

2.5. Rozpoznaje w wypowiedzi ironię i opisuje jej mechanizm. 
3. Tworzy własne wypowiedzi z uwzględnieniem reguł rządzących formułowaniem skutecznego przekazu:

3.1. Tworzy dłuższą wypowiedź pisaną i mówioną; stawia tezę lub hipotezę, dobiera argumenty, porządkuje je, hierarchizuje, dokonuje ich selekcji pod względem użyteczności w wypowiedzi, dobiera przykłady ilustrujące wywód myślowy, przeprowadza prawidłowe wnioskowanie, podsumowuje; [język obcy, matematyka, historia]

3.2. Pisze szkic interpretacyjny, w którym wyrażone opinie są poparte logiczną argumentacją; [matematyka, historia]

3.3. Pisze recenzję z książki, filmu, spektaklu teatralnego, wystawy, koncertu lub innego wydarzenia kulturalnego, w której przedstawione są najważniejsze informacje, poparte argumentami wartościowanie i uzasadniona interpretacja;

3.4. Pisze i wygłasza referat naukowy z interesującej go dziedziny; [historia, wos, etyka, religia]

3.5. Wygłasza przemówienie, wykład lub mowę innego rodzaju, dba o dźwiękową wyrazistość przekazu, w tym o tempo mowy i donośność głosu; [wos, religia]

3.6. Potrafi wypowiadać się przed kamerą i do mikrofonu, dostosowuje swoją wypowiedź do wymogów medium (czas wypowiedzi, modulacja głosu, język ciała); [informatyka]

3.7. Tworzy rozbudowane komunikaty multimedialne, dba o zawartość obrazu, infografiki, służący przekazowi montaż; [informatyka]

3.8. Stosuje uczciwe zabiegi perswazyjne, zdaje sobie sprawę z ich wartości i funkcji, wystrzega się nieuczciwych zabiegów erystycznych; [wos, wdż]

3.9. Zachowuje układ kompozycyjny swojej wypowiedzi, sporządza plan, dobiera odpowiednie słownictwo;

3.10. Tworząc wypowiedzi, dąży do precyzyjnego wysławiania się, świadomie dobiera synonimy i antonimy dla wyrażenia zamierzonych treści; [język obcy]

3.11. Stosuje różne rodzaje zdań we własnych wypowiedziach; [język obcy]

3.12. Stosuje poprawne formy odmiany rzeczowników, czasowników (w tym imiesłowów), przymiotników, liczebników i zaimków, stosuje poprawne formy wyrazów w związkach składniowych (zgody i rządu);

3.13. Opracowuje redakcyjnie własny tekst - dokonuje uzupełnień, przekształceń, skrótów, poprawek stylistycznych; [język obcy]

3.14. Dokonuje edycji tekstu napisanego w formie elektronicznej, dba o jego estetykę, czytelność i zawartość językową; [informatyka]

3.15. Potrafi sporządzić opis bibliograficzny książki i artykułu (również opublikowanych w formie elektronicznej), zrobić przypis, przygotować bibliografię do wybranego tematu;

3.16. Posługuje się bogatym słownictwem z zakresu nauki, kultury, filozofii, religii, spraw publicznych. [matematyka, wos, historia, etyka, religia]

II. Kompetencje literackie i kulturowe [uczeń/uczennica rozumie teksty kultury, których jest odbiorcą, zna kody, za pomocą których można je interpretować, potrafi o nich rozmawiać, dostrzega w nich emocje i inspiruje się nimi w refleksji o swoich doświadczeniach, odczytuje zawarte w nich myśli, umieszcza je w różnych kontekstach, dzięki nim poznaje innych ludzi, potrafi z empatią mówić o ich doświadczeniu życiowym, emocjach, myślach i światopoglądzie]

Nauczyciel/nauczycielka:

1. Inspiruje ucznia/uczennice do wykorzystywania wiedzy o kulturze w interpretacji dzieła; 
2. Wspiera ucznia/uczennice $\mathbf{w}$ procesie interpretacji;

3. Zachęca ucznia/uczennice do podejmowania samodzielnej refleksji nad tożsamością narodową i wartościami.

\section{Uczeń/uczennica:}

1. Wykorzystuje wiedze o literaturze, kulturze i estetyce do analizy i interpretacji dzieła oraz budowy własnej świadomości estetycznej:

1.1. Określa oczekiwania estetyczne związane z dziełem;

1.2. Wskazuje wykorzystane w utworze środki wyrazu artystycznego (np. z zakresu kompozycji, metod rytmizacji, operowania kontrastem) oraz objaśnia ich funkcję;

1.3. Rozpoznaje w utworze literackim oksymoron, synekdochę, hiperbolę, elipsę, paralelizm;

1.4. Rozpoznaje gatunki literackie i potrafi opisać ich cechy: epos i epopeję, tragedię, dramat szekspirowski, dramat romantyczny, powieść lub dramat naturalistyczny, powieść psychologiczną, powieść polityczną, dramat groteskowy;

1.5. Dostrzega w dziele kategorie estetyczne: tragizm, komizm, groteskę i potrafi wyjaśnić ich funkcję estetyczną oraz filozoficzną;

1.6. Rozpoznaje w dziełach sposoby kreowania świata przedstawionego oraz bohaterów;

1.7. Omawia cechy psychologiczne postaci literackich i filmowych, wyjaśnia motywy postępowania i podejmowanych wyborów, dokonuje oceny etycznej, uzasadnia ją; [etyka, religia, wdż]

1.8. Przedstawia sposoby budowania fabuły, prowadzenia narracji, przedstawiania sytuacji lirycznej;

1.9. Potrafi wyjaśnić różnice językowe $\mathrm{w}$ tekstach literackich $\mathrm{z}$ dawnych epok w stosunku do polszczyzny współczesnej, wie, gdzie szukać objaśnień niezrozumiałych słów, znaczenia słów z minionych epok uwzględnia w propozycji interpretacyjnej; [historia]

1.10. Dostrzega w odbieranych dziełach cechy charakterystyczne epoki, w której powstało; [historia]

1.11. Potrafi przedstawić najważniejsze cechy estetyki i światopoglądu epok w dziejach kultury: antyku, średniowiecza, odrodzenia, baroku, oświecenia, romantyzmu, pozytywizmu, Młodej Polski, modernizmu dwudziestowiecznego (z podziałem na dwudziestolecie międzywojenne i kulture powojenną), postmodernizmu. [historia]

2. Przedstawia propozycję interpretacyjną, w której uwzględnia różne konteksty:

2.1. W interpretacji uwzględnia kontekst historyczny powstania utworu (z zakresu historii literatury i kultury oraz - jeśli to potrzebne - historii politycznej); [historia]

2.2. Potrafi $\mathrm{w}$ interpretacji wykorzystać wiedzę o biografii autora (jeśli to potrzebne) i innych kontekstach pomagających zrozumieć genezę utworu; [historia]

2.3. Wykorzystuje w interpretacji konteksty polityczne, filozoficzne, światopoglądowe czy religijne, uzasadnia ich wykorzystanie; [wos, historia, etyka, religia]

2.4. Odczytuje w dziełach treści alegoryczne i symboliczne, potrafi wyjaśnić znaczenie alegorii oraz uzasadnić odczytanie symbolu; [historia]

2.5. Przedstawia interpretację porównawczą utworów, wskazuje ich cechy wspólne i różnice;

2.6. Wykorzystuje klasyczne dzieła literackie i inne teksty kultury do refleksji nad ogólnoludzkimi problemami egzystencjalnymi, etycznymi i światopoglądowymi; [historia muzyki, historia sztuki, filozofia, kultura antyczna, etyka, religia] 
2.7. Porównuje dzieła z różnych dziedzin twórczości - np. utwory literackie z filmami i spektaklami teatralnymi, dzieła malarskie z utworami muzycznymi, itd., omawia specyfikę poszczególnych dziedzin twórczości i wynikające $\mathrm{z}$ tego konsekwencje dotyczące estetyki oraz wymowy;

2.8. Porównuje funkcjonowanie tych samych motywów w różnych dziełach z tej samej epoki i innych epok oraz dziełach z poszczególnych dziedzin twórczości; [historia]

2.9. Poddaje analizie obecne w dziełach wartości uniwersalne i narodowe, uzasadnia ich odczytanie, ustosunkowuje się do nich, podaje argumenty przemawiające za jego opinią. [historia, wos

3. Podejmuje refleksje nad specyfiką kultury polskiej, tożsamością narodową, wartościami:

3.1. W klasycznych dziełach literackich i innych tekstach kultury wskazuje elementy kodu kultury polskiej, europejskiej i ogólnoludzkiej; [historia, wos, historia muzyki, historia sztuki, kultura antyczna, filozofia]

3.2. Poddaje refleksji własną tożsamość kulturową, potrafi przedstawić i omówić elementy innych tożsamości; [wdż, wos, filozofia, historia, etyka, religia]

3.3. Dostrzega w literaturze i sztuce konflikty wartości, potrafi wskazać źródła tych konfliktów, podejmuje refleksję nad możliwością bądź niemożliwością ich rozwiązania. [wos, wdż, etyka, religia]

Na koniec szkoły branżowej II stopnia absolwent/absolwentka zdaje egzamin maturalny na poziomie podstawowym. 
Konieczne jest opracowanie listy lektur. Ponieważ jednak ten element podstawy programowej budzi zawsze najwięcej kontrowersji, można to zostawić na później. Zwłaszcza że to lektury powinny być dostosowane do wymagań, nie wymagania do lektur. Szczególnej dbałości wymaga opracowanie listy lektur dla młodszych klas. Warto jednak przyjąć, że liczba lektur obowiązkowych nie powinna być zbyt obszerna. Wydaje się, że obowiązująca w dotychczasowej podstawie programowej (z 2008 roku) liczba (co najmniej cztery pozycje książkowe rocznie w klasach IV - VI, co najmniej pięć pozycji książkowych w gimnazjum i 13 pozycji w całym cyklu w liceum i technikum) jest rozsądna. Można zaproponować następujące rozwiązanie:

- W edukacji przedszkolnej i wczesnoszkolnej o tytułach i liczbie czytanych lektur decyduje nauczyciel,

- w klasach IV - VI przynajmniej po cztery pozycje książkowe rocznie, o tytułach (można stworzyć listę lektur rekomendowanych, która jednak musi być otwarta i korygowana lub uzupełniania rokrocznie, żeby uwzględniać w niej nowe pozycje) i ostatecznej liczbie lektur decyduje nauczyciel,

- w klasach VII - VIII przynajmniej po pięć pozycji książkowych rocznie, połowę tytułów warto wskazać jako obowiązkowe, o pozostałych tytułach decyduje nauczyciel, jak w klasach IV - VI można stworzyć listę lektur rekomendowanych,

- w klasach I - III liceum na poziomie podstawowym przynajmniej po pięć pozycji książkowych rocznie, powinny być podane lektury bezwzględnie obowiązkowe z klasyki, ale o części lektur powinien decydować nauczyciel w porozumieniu z uczniami, na tym poziomie konieczna jest lista tytułów rekomendowanych,

- w klasie IV liceum na poziomie podstawowym przynajmniej trzy pozycje książkowe, jedna bezwzględnie obowiązkowa, dwie do wyboru z listy tytułów rekomendowanych, korygowanej rokrocznie,

- w klasach I - IV liceum na poziomie rozszerzonym dodatkowo przynajmniej pięć pozycji książkowych rocznie, tytuły wybierane przez nauczyciela w porozumieniu z uczniami,

- w klasach I - IV technikum i pięcioletniego liceum przynajmniej po cztery pozycje książkowe rocznie, liczba lektur i tytuły jak w liceum w klasach I - III,

- w klasie V technikum i pięcioletniego liceum przynajmniej dwie pozycje książkowe, liczba i tytuły jak w klasie IV liceum,

- w klasach I - III szkoły branżowej I stopnia przynajmniej po dwie pozycje książkowe rocznie, wybrane przez nauczyciela z listy tytułów rekomendowanych,

- w klasach I - II szkoły branżowej II stopnia przynajmniej po pięć pozycji książkowych rocznie, tytuły obowiązkowe jak w liceum, o pozostałych tytułach decyduje nauczyciel, wybiera z listy pozycji rekomendowanych korygowanej rokrocznie. 
Polonistyka. Innowacje 
Polonistyka. Innowacje Numer 12, 2020 
